\title{
دور الأسرة والمدرسة في الوقاية من الجريمة دراسة تحليلية ميدانية في مجتمع الامارات
}

\author{
أ.د سعيد ناصف \\ أستاذ- جامعة عجمان - قسم علم الاجتماع - كلية الإنسانيات والعلوم \\ د. إنعام يوسف \\ أستاذ مساعد- جامعة عجمان - قسم علم الاجتماع - كلية الإنسانيات والعلوم \\ مدرس - جامعة عين شمس - قسم علم الاجتماع - كلية الأد/ب
}

مستخلص. يتمثل الهدف الرئيسي للدراسة في التعرف على الدور الذي تلعبه مؤسسات التتشئة الاجتماعية (الأسرة والمدرسة) في حماية الثباب في دولة الإمارات العربية المتحدة من الجريمة، وذلك من خلال إجراء دراسة ميدانية

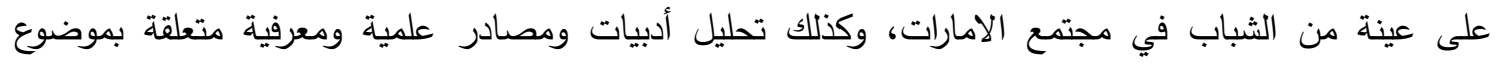

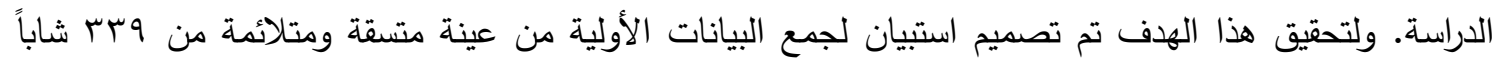

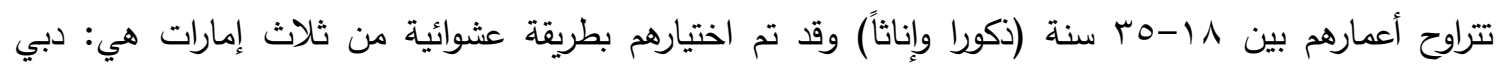

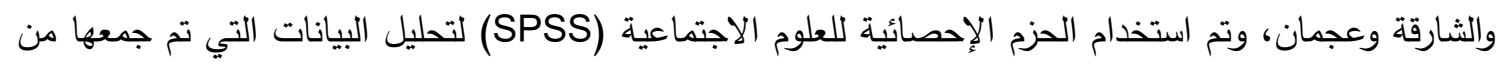
خلال الاستبيان، واستخدمت أساليب تحليلية إحصائية مثل مقياس ترتيب الأهمية، ونسبة معدل الأهمية والمتوسط الإن المرجح للأهمية (الانحدار المتعدد - التباين) مع التركيز على متغير النوع فى كل المقياس. وقد توصلت الدراسة إلى مجموعة من النتائج منها: - أهمية دور الأخصائي الاجتماعي والأخصائي النفسي ودمج خطة عمل كليهما في الخطة المدرسية، ويوحد الجهود لتحقيق أهداف حماية الطلاب من المشاكل الاجتماعية والنفسية التي تؤدي إلى ارتكاب الجريمة.

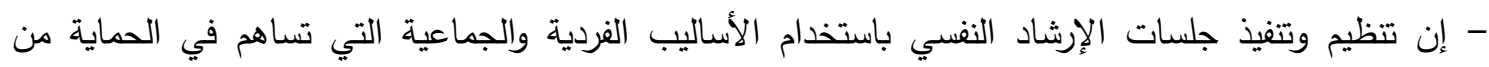
الجريمة والسلوك الإجرامي تظهر أقل نسبة من الأهمية، مع اختلاف كبير في النوع. 
- أهمية دور التشئَة الاجتماعية عن طريق توفير الطرق لحل المشاكل التي يواجهها الثباب هو أعلى نسبة مئوية من أي قياسات أخرى تقع تحت هذا المجال. مع التباين بين الجنسين. - تأتي أهمية نقل التراث التقافي والاجتماعي من جيل إلى جيل والالتزام بالتكامل مع مؤسسات التتشئة الاجتماعية الأخرى عند أدنى مستوى من الأهمية. كما إن العقبات التى تحول دون فاعلية دور الألى الأسرة والمدرسة في منع الجريمة تتمثل في ضعف التعليم الذي يعيق تفعيل دور عمليات التتشئة الاجتماعية. الكلمات المفتاحية : الأسرة ، الجريمة ، المدرسة ، الوقاية من الجريمة ، التتشئة الاجتماعية ، مؤسسات التنشة الاجتماعية .

أساسى وفاعل في تتمية المجتمع، والمحافظة على استقراره، وأمنه. فهى العملية التي يكتسب الفرد من خلالها ثقافة مجتمعه، التي تحوى سلوكيات وعادات وقيم ومعتقدات تبنى في إطارها شبكة العلاقات

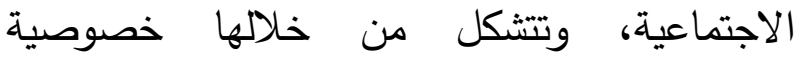
المجتمع، كما أنها تعتبر بمثابة الأسس والقواعد التي تعمل على التفاعل والتواصل بين أفراده كافة، إضافة إلى تحديد وصياغة اتجاهات الأفراد، وتشكيل شخصياتهم بما يتواءم مع طبيعة ذلك، ومتطلبات المجتمع أيضاً. لذلك كان هناك عدد من المؤسسات الإجتماعية الرئيسية التي تعمل وبشتى الطرق على القيام بتلك العملية " التنشئة الاجتماعية " بالدرجة التي تحقق الأهداف المرجوة منها، لتنمية وتطوير المجتمع، ومن أهمها الأسرة، والمدرسة كأولى تلك المؤسسات التي تعمل وبشتى الطرق، والآليات على دعم الأفراد وتربيتهم، وتشكيل شخصياتهم وسلوكهم لتحقيق الدمج الاجتماعى، والإرشاد، والتوجيه الذي من شأنه حماية وحفظ الأمن الاجتماعى، من خلال حماية

\section{المقدمة}

تعتبر عملية التشئة الاجتماعية علية معقدة ومتشابكة الأطراف، وترجع أهميتها إلى الدور الهام الذي تلعبه في تشكيل شخصية الفرد. وتختلف أساليب التشئة الاجتماعية من مجتمع لآخر. ففي المجتمعات التقليدية كانت الأسرة تقوم بالدور الأساسي في غرس قيم المجتمع ومعاييره في الأبناء، حيث كان الطفل يكتسب المعرفة والقيم من الوالدين والأقارب المحيطين به. أما في المجتمعات الحديثة، فقد أصبحت عملية التشئة الاجتماعية أكثر صعوبة وتعقيد، فالأسرة لم تعد هي المؤسسة الأساسية التي تربي الفرد وتغرس فيه قيم المجتمع، أو التي تزوده بالمعارف المختلفة، بل أصبح هنالك مؤسسات عديدة تقوم بهذه الوظيفة: المدرسة وجماعة الأصدقاء ووسائل الاعلام والمؤسسات الدينية....وغيرها. ومن ثم، تُعد عملية التنشئة الاجتماعية من أهم العمليات الاجتماعية التي يقوم بها أفراد المجتمع وفقاً لما تهدف إليه وتقوم عليه من تقويم للسلوك، والتربية الاجتماعية، وتحديد، بل وتشكيل للأدوار الاجتماعية والمكانات المختلفة التي تسهم، وبشكل 
التتشئة الاجتماعية الدور الأساسى في تحقيق ذلك

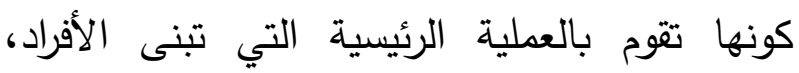

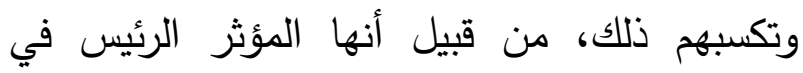

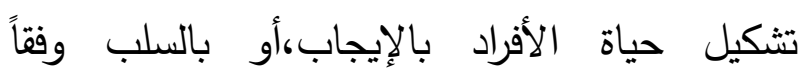
ومتضمناتها، ومدى الإلتزام بإجراءاتها، وعناصرهاه

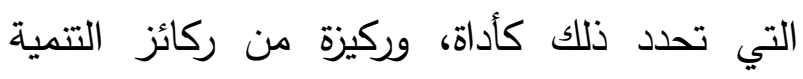

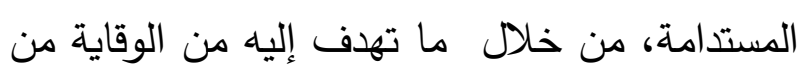

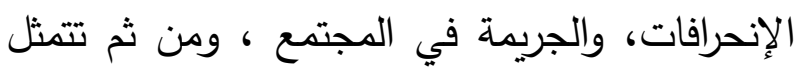
إثكالية الدراسة الراهنة في تساؤل رئيس مؤداه: ما طبيعة الدور الذى تقوم به مؤسسات التنشئة الاجتماعية ( الأسرة - المدرسة ) في وقاية الثباب بدولة الإمارات العربية المتحدة من الجريمة. ثانياً: أهمية الدراسة:

تتمثل الأهمية النظرية للدراسة في الكثف عن لأناء الدور الذي تقوم به المؤسسات الاجتماعية وخاصة

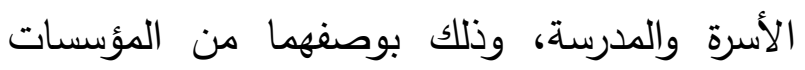

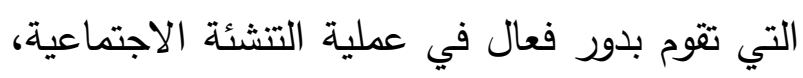
من حيث إكساب الطلاب القيم الايجابية التي لهي تحميهم من الوقوع في الجريمة بأشكالها المختلفة.

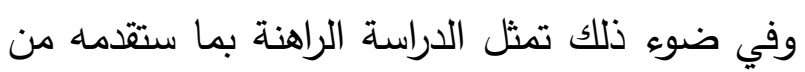
تحليلات نظرية إسهاماً مهماً يضاف إلى التراث النظري المتوافر في مجالي علم الاجتماع العائلي وعلم الاجتماع الجنائي بصورة خاصة. فى حين تتمثل الأهمية التطبيقية للدراسة في محاولة الهئة الوصول إلى الآيات، والإستراتيجيات اللازمة لتقويم لتهيه

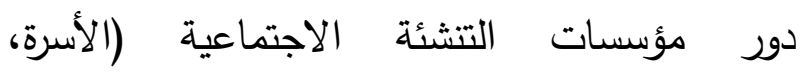

الأفراد، والإحالة دون تعرضهم لأى شكل من أشكال الإنحراف الاجتماعي. وهو الأمر الذي يؤكد على مدى أهمية الدور الاجتماعى الذى تقوم به كلاً من الأسرة، والمدرسة الأية

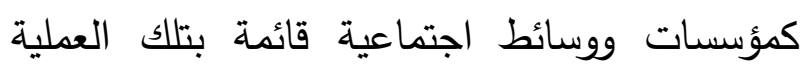
الهامة التي يتوقف عليها، وعلى مدى تقويمها، والإهتمام بها إنتاج الأفراد ذوى الكفاءات، والمهارات

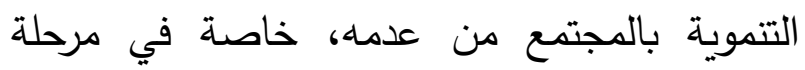
الثباب التي تعد من أهم المراحل العمرية للفرد لما بالئه لها من خصائص اجتماعية، وتنموية فعّالة تتمثل في لهني القدرة على البناء، والعطاء، والتنمية، والتطوير • وهو وتئه

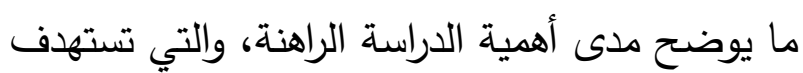

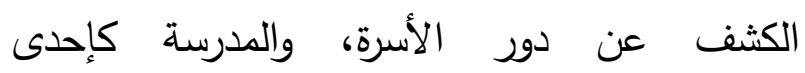
المؤسسات الاجتماعية القائم عليها تقويم السلوكيات الاجتماعية خاصة لدى الشباب، ووقاية الأفراد من الإنحراف، والجريمة خاصة بمجتمع الإمارات العربية

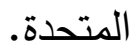
أولاً: إشكالية الدراسة: إنطلاقاً من أن الثباب هم سواعد المجتمع ومصدر من مصادر رفاهيته وتقدمه، لما يمتلكونه من قدرة

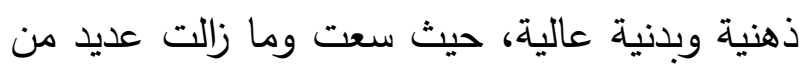
المجتمعات، وبشتى الطرق إلى غرس، وتتمية السلوكيات الإيجابية لديهم لتقويم قدراتهم المتباينة لما لذلك من دور فاعل فى تعزيز انتماءاتهم الوطنية وإتاحة الفرص لهم للتعبير عن ذواتهم، وقدراتهم، وإبداعاتهم الفكرية، والفنية، والمعرفية، ولما لمؤسسات 
والمدرسة)، والعمليات الاجتماعية التي تتضمنها رابعاً: تساؤلات الدراسة:

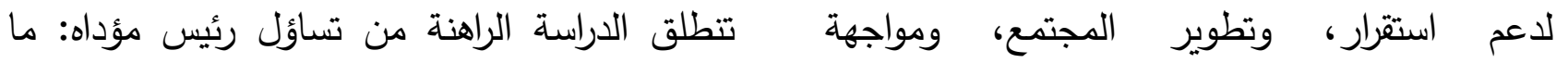

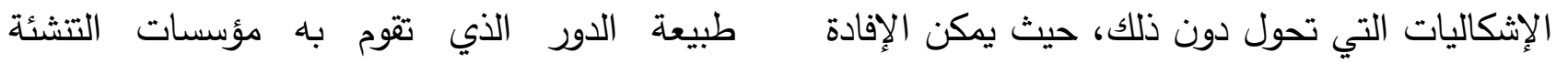
الاجتماعية في وقاية الثباب بدولة الإمارات العربية المتحدة من الجريمة، ويتضمن هذا التساؤل عدد من الإنسائ

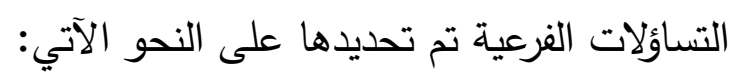
ا ما أهمية وطبيعة دور كلاً من الأسرة، والمدرسة

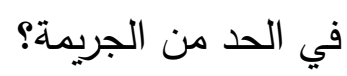
ץ- ما طبيعة دور الأسرة كإحدى مؤسسات التنشئة

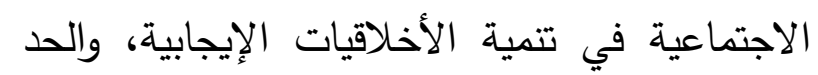
من السلوك الإنحرافى والجريمة؟ r- ما دور المدرسة في مواجهة الجريمة، ودعم الأخلاقيات الإيجابية؟

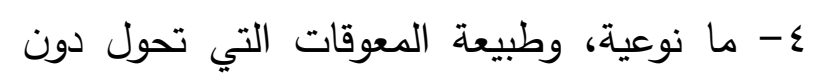
تفعيل دور مؤسسات التتشئة الاجتماعية في الوقاية

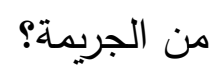
0- ما مالجيدة أهمية دور الأخصائى الاجتماعى

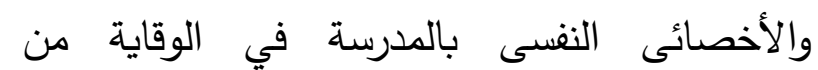

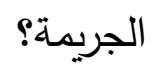
خامساً: مفاهيم الدراسة: 1- مفهوم الدور الاجتماعي: يعَّرف "أنتونى جيدنز" الأنه

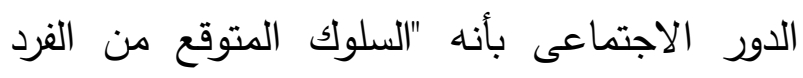

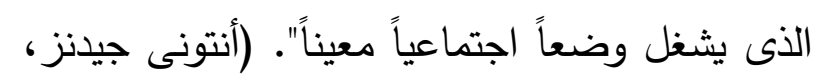

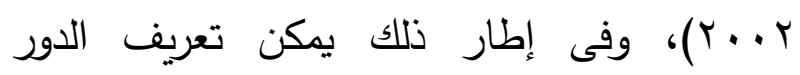
من نتائج الدراسة وتوصياتها في تحقيق ذلك. ثالثًاً: أهداف الدراسة: تتحدد أهداف الدراسة الراهنة في هدف رئيس مؤداه: التعرف على الدور الذي تقوم به مؤسسات التنشئة

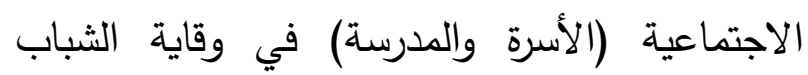
بدولة الإمارات العربية المتحدة من الجريمة. وينبثق من هذا الهدف عدد من الأهداف الفرعية تتمثل في الأتى: من ه: 1- الكشف عن أهمية دور كلاً من الأسرة، والمدرسة في الحد من الجريمة. r- التعرف على دور الأسرة كإحدى مؤسسات التتشئة الاجتماعية في تتمية الأخلاقيات الايجابية، والحد من السلوك الإنحرافى والجريمة. ץ- معرفة دور المدرسة في مواجهة الجريمة، ودعم الإحرفي ولجرية الأخلاقيات الإيجابية. ع- التعرف على المعوقات التي تحول دون تفعيل

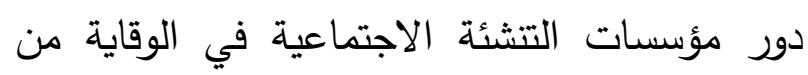
الجريمة 0- الكثف عن أهمية دور الأخصائى الاجتماعى،

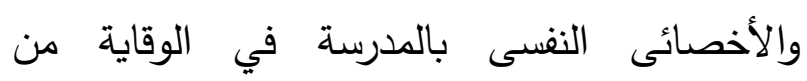
الاجتماعى إجرائياً بأنه: السلوك أو الفعل الذي يقوم 
مجموعة من الأنساق، والنظم الاجتماعية التي تقوم بإكساب الفرد القيم، والعادات، والتقاليد، والمعتقدات، والموروثات الاجتماعية التي تشكل شخصيته من الناحية الاجتماعية، وتدعم السلوكيات بما يحقق الأهداف التتموية للمجتمع، وتتمثل في (الأسرة،

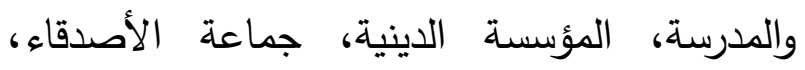
المؤسسة الإعلامية.. وغيرها من المؤسسات الأخرى الفاعلة في هذا المجال. ع- مفهوم الجريمة: يُعرّف "دوركايم" الجريمة بأنها " تعبير عن انعدام شعور التضامن الاجتماعي لدى الفرد الذي يفسره عدم تشرب الفرد للقيم، والمبادئ الاجتماعية الأساسية التي تبعد عن هذا التضامن

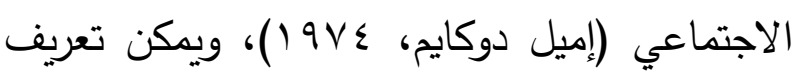
الجريمة إجرائياً بأنها: كل فعل ينتج عن مخالفة الأنماط السلوكية السوية، والمرغوب فيها إجتماعياً سواء كانت تلك الرغبة بنص قانون، أو وفقاً لعرف، أو ثقافة، مما يؤدى إلى عدم استقرارالمجتمع، ويبرهن على ضعف دور القائمين بعمية التشئة الاجتماعية، وخاصة كلاً من الأسرة، والمدرسة. 0- مفهوم الوقاية من الجريمة: يمكن تعرّيفها إجرائياً بأنها: الجهود التي قد تبذلها الدولة، والمجتمع، والأفراد من خلال المؤسسات الاجتماعية المختلفة، وفقاً لعدد من البرامج، والأنشطة، والإستراتيجات اللازمة في شتى مجالات الحياة للحفاظ على حالة

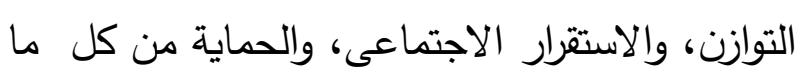
يحول دون تحقيق ذلك.
به الأفراد أو المؤسسات وفقاً لعدد من المتغيرات الاجتماعية وصولاً لتحقيق هدفاً ما. r- مفهوم التتشئة الاجتماعية: تُعرّف بأنها "عملية تهدف إلى توجيه المجتمع من خلال توفير قاعدة مشتركة للمعايير، والخبرات الجماعية" (حسن

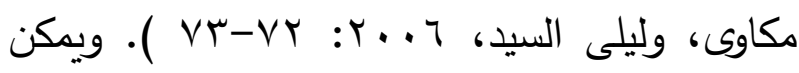
تعريفها أيضاً بأنها: العملية الاجتماعية التي يكتسب الغرد من خلالها ثقافة، وسلوكيات مجتمعه، مما لهري يحفز من إدماجه، وتكيفه اجتماعياً، وهو ما يساعد على تحقيق الاستقرار المجتمعى. وإجرائياً يمكن تعريف التشئة الاجتماعية بأنها: العملية التي يكتسب الفرد من خلالها التقافة السائدة في المجتمع. وأن عملية التششئة لا تقتصر على مرحلة الطفولة فقط، بل إنها عملية مستمرة من المهد إلى اللحد، وتساهم فيها جميع الجماعات الاجتماعية التي يتعامل معها الفرد، خاصة الأسرة، فهي التي تضع حجر الأساس في بناء شخصية الطفل، فمن خلال تلك المؤسسة(الأسرة) يتلقى الأبناء تدريباتهم الأولى في الحياة. r- مفهوم مؤسسات التشئية الاجتماعية: وتعبر عن الن النظم الاجتماعية التي ينهض عليها تقويم السلوكيات الاجتماعية بما يتفق ومتطلبات المجتمع التتموية، وهي التي تسهم في تكوين، وتشكيل شخصية الفرد، ولها دور كبير في تحديد مدى التوافق النفسى لله من عدمه وفقاً وطبيعة أهدافها، العناصر التى تستند عليها لتحقيق ذلك. ويمكن تعريفها إجرائياً بأنها: 
تشكل مجالاً أساسياً للمتخصصين في العلوم القانونية، إضافة إلى المتخصصين في كل من علم الاجتماع الجنائي وعلم النفس الجنائي، ومن ثم، فهناك دراسات عديدة في مجال دراسة الجريمة. ويمكننا في الدراسة الراهنة أن نعرض لنماذج من درات دران

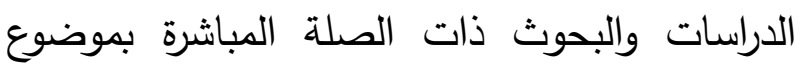
دراستتا، مع الوضع في الحسبان أن تكون دراسات

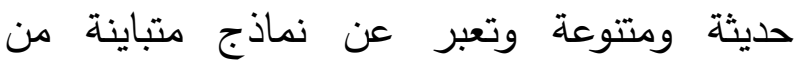

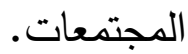

1- دراسة عايش المطيرى، بعنوان: دور الأسرة والمدرسة في الحد من السلوك الإنحرافى في مدارس

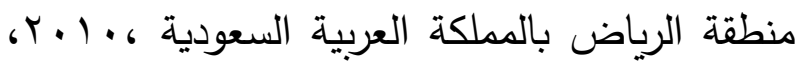

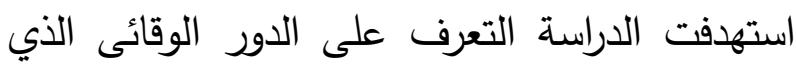

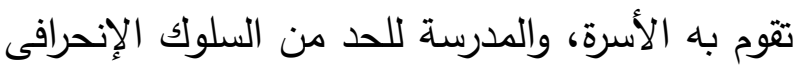
بمنطقة الرياض بالمملكة العربية السعوية، وذلك من وجهة نظر المعلمين، والطلاب. والتحقق فيما إذا كان هناك فروق ذات دلالة إحصائية في تصورات ولطين الطلاب نحو دور الأسرة في الحد من السلوك الانحرافي في مدارس منطقة الرياض تعزى لمتغيرات (مكان الإقامة ومستوى دخل الأسرة ومستوى تعليم الأب ومستوى تعليم الأم). وقد اعتمدت الدراسة على المنهج الوصفى التحليلي، إضافة إلى البحث التحليلي الميدانى من خلال المسح الاجتماعى بالعينة، والاعتماد على أداة

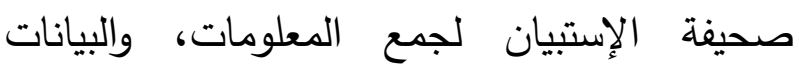
المرتبطة بموضوع الدراسة، حيث قد تم التطبيق على
7- مفهوم المدرسة :تعبر عن " أولى المؤسسات التعليمية بعد الأسرة في رعاية الأطفال، والعناية بهر التهوني كما تعد بمثابة النسق المؤسسي المقام من قبل

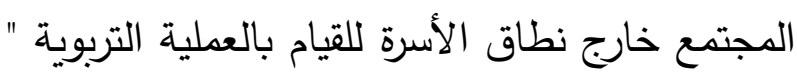

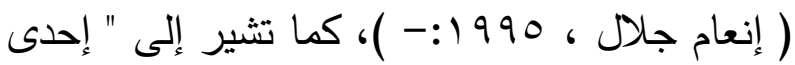
آليات المجتمع لنقل الثقافة من جيل لآخر ، إضافة إلى السعي لتتمية المهارات، وتقويم السلوكيات

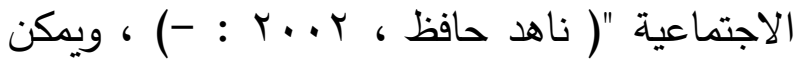
تعريفها إجرائياً بأنها " إحدى مؤسسات التنشئة الاجتماعية ، والقائم بالعملية التربوية ، لتتمية المهارات ، وخلق السلوكيات الإيجابية التي تدعم ، لإعله وتشكل الثخصيات الاجتماعية ، بما يتوافق وطبيعة ما يهدف إليه المجتمع من تتمية وتطوير ..." .

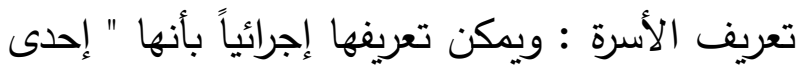
مؤسسات التنشئة الاجتماعية وهى الجماعة الاجتماعية التي تتشكل من الزوج والزوجة والأبناء الذين تربطهم علاقات اجتماعية عاطفية وثقافية ويشتركون في وحدة اقتصادية واحدة ويتعاونون معاً لتربية وترشيد وتأهيل الأفراد بتلك الأسرة ..." . سادساً: الدراسات السابقة: لا شك في أن موضوع التنشئة الاجتماعية عموماً يعتبر من الموضوعات المهمة بالنسبة للمتخصصين في العلوم الاجتماعية بصورة عامة، والمتخصصين في علم الاجتماع وعلم النفس بصورة خاصة، ولذلك الك قثمة دراسات وبحوث عديدة في هذا المجال. أما موضوع الجريمة، فهو أيضاً من الموضوعات التي 
الفكرى. رؤية نظرية ودراسة تحليلية "، ^...r،

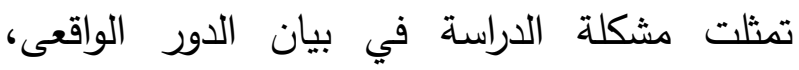

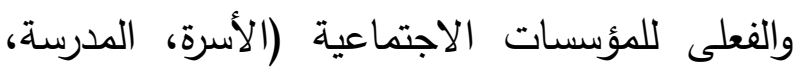
المسجد، والإعلام) في تحقيق الأمن الفكرى، والوقاية

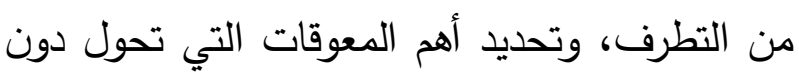
فاعلية دور تلك المؤسسات الاجتماعية في تحقيق الأهداف المرجوة. هذا وقد اعتمدت الدراسة على الدي

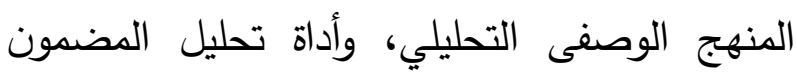

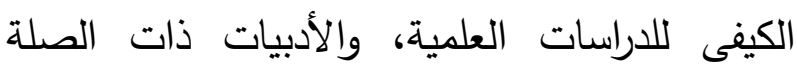
بموضوع الدراسة سواءً أكان ذلك بطريقة مباشرة أو غير مباشرة للقيام بتحليلها ودراستها، دراسة استقرائية على نحو يمكن من خلاله استخلاص ما يتصل

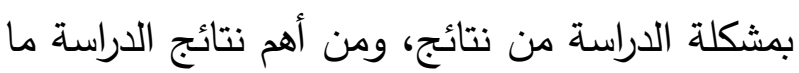
يلى: أن الأسرة تعد أداة النقل الثقافية والإطار الثقافي للطفل، فعن طريقها يعرف الطفل ثقافة عصره وبيئته على السواء، ويعرف الأنماط الهامة السائدة في

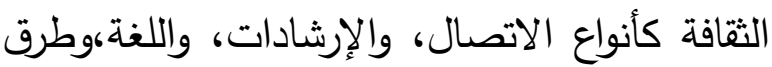

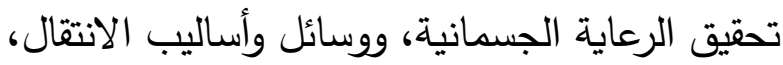
وتبادل السلع والخدمات، ونوع الملكية ومعناها

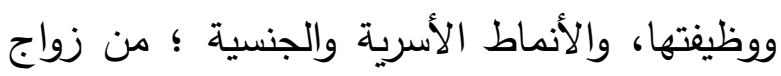
وطلاق، وقوانين وقيم اجتماعية. كما أوضحت نتائج الدراسة أيضاً أن الإخفاق في وفئن الحياة الأسرية من أهم الأسباب المؤدية إلى جنوح الإنها الأفراد واكتساب بعض الصفات السيئة، بل وفشلهح

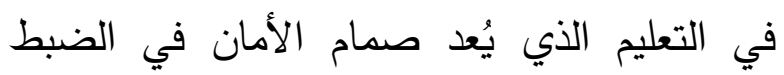
الاجتماعي، ومحاربة الجنوح الفكري والأخلاقي لدى لاعي
عينة عمدية قوامها ، ،11 مفردة من المعلمين، و . .ع مفردة من الطلاب بمدارس منطقة الرياض. وقد توصلت الدراسة إلى عدد من النتائج، من أهمها:

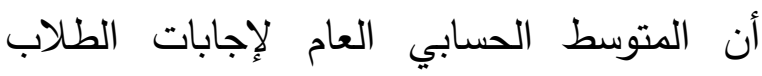

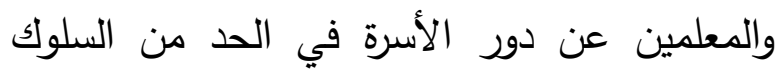
الاتحرافي قد جاء مرتفععاً. وهذا يدل على الدور الفاعل للأسرة السعودية في الحد من السلوك الانحرافي من وجهة نظر (أفراد عينة الدراسة)، إضافة إلى أهمية الدور التربوي الذي تقوم به الأسرة في تحقيق الضبط الاجتماعي. كما أوضحت النتائج أن المتوسط الحسابي العام لإجابات الطلاب والمعلمين عن دور المدرسة في الحد من السلوك الانحرافي قد جاء مرتفعاً. فالمدرسة لها دور تربوي يتمثل في غرس القيم الاجتماعية والدينية والتربوية في الطلاب، مما يقلل أو يساعد الدي في الحد من السلوك الانحرافي. كما أوضحت النتائج أيضاً وجود فروق ذات دلالة إحصائية بين تصورات

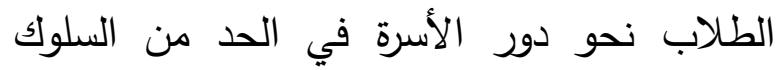
الانحرافي في مدارس منطقة الرياض بالمملكة العربية

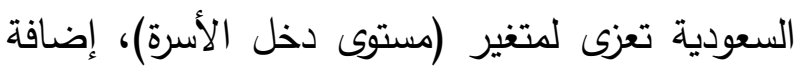
إلى وجود علاقة بين المستوى التعليمي ودرجة تحقيق الضبط الاجتماعي في الأسرة، ووجود علاقة بين الأمية وعدم تحقيق الضبط الاجتماعي للأسرة. (عايش

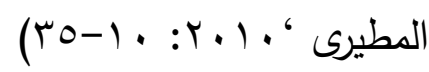
r - دراسة سعيد حمدان، وسيد عبد الله، بعنوان:

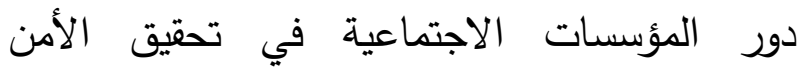


متوسطة الحجم وفي المدن الكبيرة في هولندا. واستخدمت الدراسة المنهج الوصفي التحليلي للكثف عن المتغيرات وتناولت الفرضيات والسؤال الرئيسي من الدراسة هو: دراسة العلاقة بين المتغيرات في ثلاثة مجالات هامة في الأبوة والأمومة في مرحلة المراهقة، أي مجال الانسجام الدعم المدرك الذي تقدمه الاسرة، ومجال الاستقلالية التي يمنحها الوالدان، ونطاق النزاع اي والسلبية في العلاقة بين الوالدين والمراهقين، وكل من العدوان والانحراف. وكان السؤال البحثي الرئيسي هو دراسة: ما إذا كانت الأبوة والأمومة ونوعية الأم والمراهقة ترتبط العلاقة بالعدوان والجنوح بنفس الطريقة بالنسبة للأولاد المغاربة والفتيات الهولنديات. وهدف الدراسة تمثل في التعرف على ما إذا كانت أنماط الارتباط بين نوعية العلاقة بين الوالدين والمراهقين من ناحية، والعدوان والجنوح من جهة أخرى هي نفسها بالنسبة للبنين والبنات من أصل هولندي ومغربي يعيشون في هولندا. وأوضحت نتائج الدراسة أنه لا توجد اختلافات في كلا المجموعتين

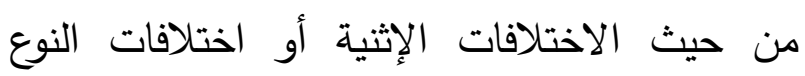
(اناث/ذكور) في أنماط الارتباط في العلاقة بين الأبوين والمراهقين، ومن حيث الدعم والاستقلالية والإفصاح والسلبية والعدوان والجنوح. كانت الأنماط متشابهة إلى حد كبير فى كلتا المجموعتين. ووجد أن العلاقة السلبية في جزئى الدراسة ترتبط ارتباطاً
أفراد المجتمع. إضافة إلى التأكيد على أن المدرسة تتحمل مسؤولية جسيمة في تحصين الطلاب ووقايتهم من أي انحراف فكري باتجاه الغلو، والإنحراف، من خلال الحوار مع الطلاب، وفتح المجال أمامهم للتعبير عن آرائهم بكافة الوسائل، وفي مختلف الأنشطة التعليمية، وترسيخ ثقافة التسامح لديهم كآلية دن آليات الوقاية من التطرف، والإنحراف، وذلك من خلال تطعيم المناهج التعليمية بإطار متكامل من القيم والمثل والمعتقدات والأخلاقيات التي تخدم المجتمع في تحقيق الأمن الفكري والتسامح الاجتماعي. (سعيد حمدان، سيد عبد الله،م . . ץ: 0- • ب). r- دراسة Veroni, I. Eichelsheim and et بعنوان: الجمع بين علاقة الوالدين بالمراهقين، والعدوان والجنوح. دراسة على أثثين من العينات الإثثية

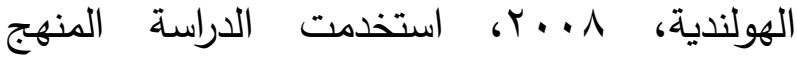
الوصفي التحليلي وتكونت الدراسة من جزئين شمل الحزء الأول عدد ب^ من المراهقين و الجزء

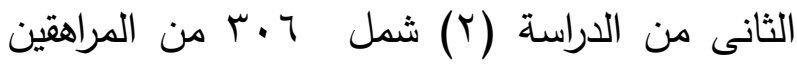

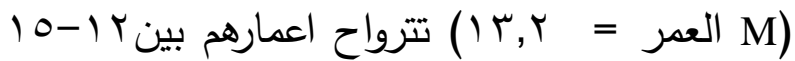
سنة من المراهقين الذين يكونون جزعً من المجتمع، وتتكون العينة من إثنين الأصل المغربي والهولندي الذين يعيشون في هولندا وكانت العينة قد اختيرت من المراهقين المعرضين للخطر، وتم ت تعبئة الاستبيانات في البيئة المدرسية، ووافقت عشر مدارس على المشاركة؛ وكانت جميع هذه المدارس 
تراجع أدوار مؤسسات التتشئة الاجتماعية الأخرى

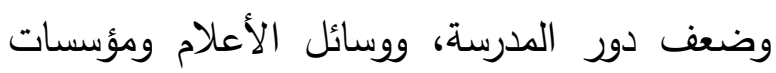

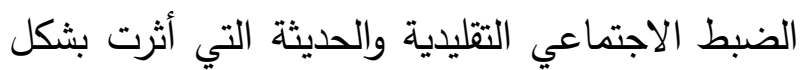

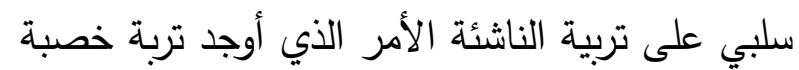

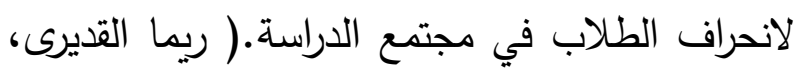
$\cdot(r \cdot T$

0- دراسة ديكوفيتش، جانسنس، وفان أس، بعنوان:

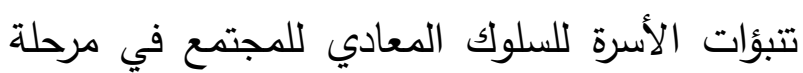

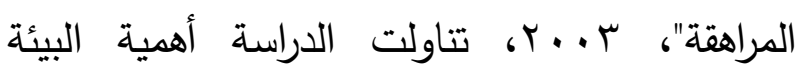

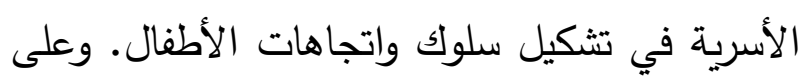
وجه الخصوص، في نوعية العلاقة بين الطفل والأبوين، جنباً إلى جنب مع مهارات الأبوة والأمومة، وهي المجالات الرئيسية ذات الأهمية في هذه دراسة.

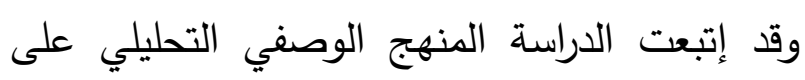

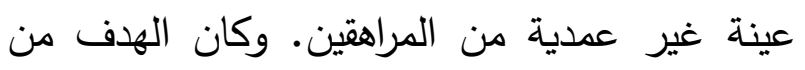
هذه الدراسة هو دراسة القدرة المشتركة والفريدة من عندين الجوانب المختلفة من أداء الأسرة للتنبؤ بالمشاركة

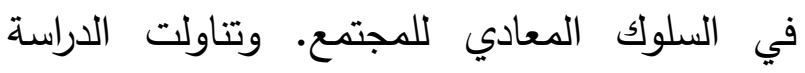
الحالة الاجتماعية والاقتصادية للأسرة، والخصائص المعادي

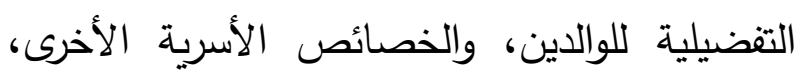

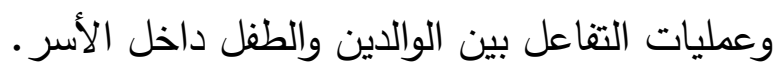

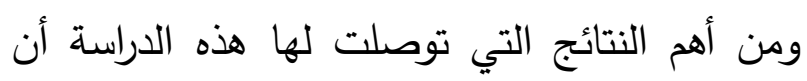
العوامل القريبة مثل التفاعل بين الوالدين والطفل كانت هامة في المساعدة على تتبؤات للسلوك

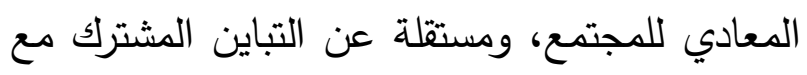

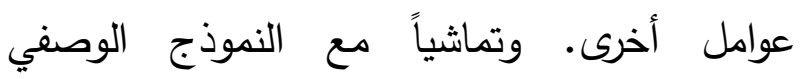

Veroni, I. Eichelsheim, وثيقاً بالعدوان والجنوح (Buist.et,2009). 4- دراسة ريما القديرى، بعنوان: التنشئة الأسرية وعلاقتها بانحراف الطلاب. دراسة حالة لدحافظة

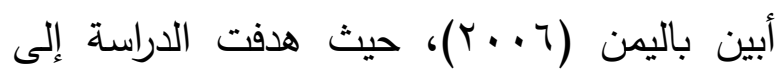

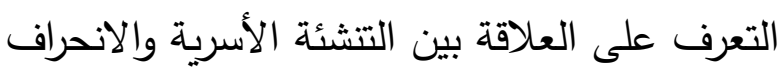
ومعرفة الأسباب التي تؤدي إلى ضعف لعن عملية التتشئة الأسرية، وتحديد أثار وانعكاسات الانحراف

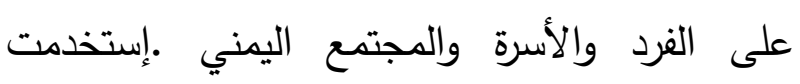

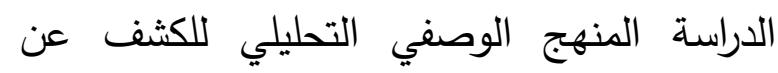
التغيرات التي طرأت على طبيعة، وبنية الأسرة ووصف وتشخيص التشئة الأسرية وعلاقتها بالانحراف الاجتماعي، إضافة إلى المنهج المقارن لإبراز أوجه الثبة والاختلاف بين الاتجاهات والقيم

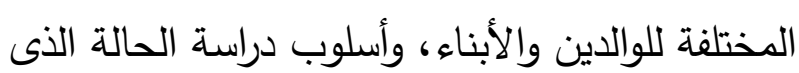
يعد جزء من هذه الدراسة، وأداة أساسية للتعمق في والتئي دراسة الظاهرة، و قد استخدمت الاستبانة، والمقابلة

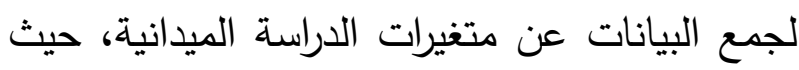
قد تم التطبيق على عينة تتكون من · · ا طالب من لن الذكور وأسرهم.

وقد خلصت الدراسة إلى أن تأثير التغيرات الاقتصادية والاجتماعية والثقافية والتربوية ساعدت الت التيل على الانحراف من حيث أن انتثار رقعة الفقر والن وانخفاض دخل الأسرة، وارتفاع عدد أفراد الأسرة، والوضع الاجتماعي، والتعليمي، وصعوبة الحياة

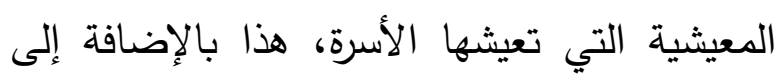


وفي نوعية أسباب الانحراف مقارنة بالعلاقات بين الأفراد. وكان جنوح الأقران أقوى ارتباط بالجنوح وفقاً

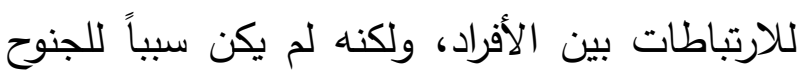

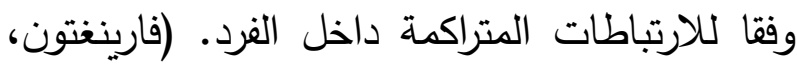
لويبر ، ين، وأندرسون سج، 1998). تعليق على الدراسات السابقة:

تناولت الدراسات السابقة موضوع التنشئة الاجتماعية

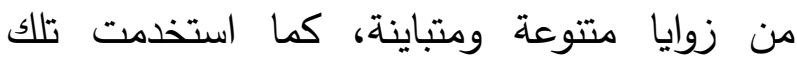
الدراسات مجموعة من الأساليب الهنهجية والإجراءات التي تتناسب وطبيعة موضوعات الدراسة من ناحية، وخصوصية مجتمعات الدراسة من ناحية أخرى. وقد توصلت تلك الدراسات إلى نتائج محددة وحصو

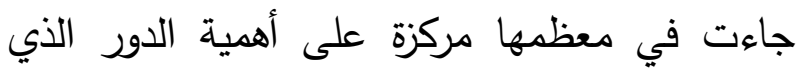
تقوم به الأسرة كمؤسسة اجتماعية في مجال التتشئة الاجتماعية للأبناء. كما أوضحت دراسات أخرى لئه مدى تأثير الظروف الاقتصادية والاجتماعية للأسرة

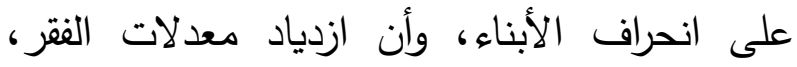

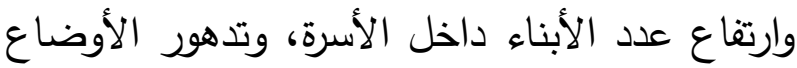

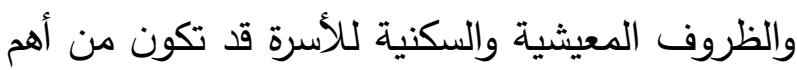

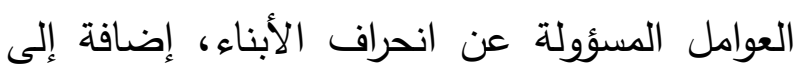
عوامل أخرى مثل التثكك الأسري بأشكاله وأنماطه

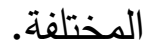

ولقد أفاد الباحثون من تلك الدراسات في بلورة موضوع الدراسة من جانب، وتحديد المفاهيم والإجراءات المنهجية المناسبة للدراسة الراهنة من جانب آخر، فضلاً عن مقارنة النتائج التي توصلت
المفترض، فإن تأثيرات العوامل البعيدة مثل الخصائص التفضيلية للوالدين والعوامل السياقية مثل

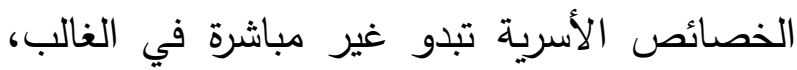

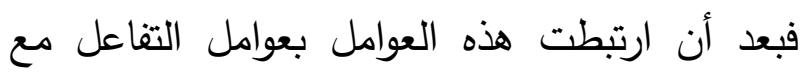
الوالدين، لم تعد هذه العوامل مرتبطة ارتباطاً وثيقاً

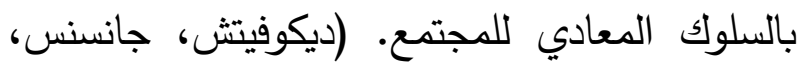

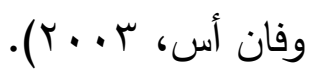
6- دراسة فارينغتون، لويبر، ين، وأبن، وأندرسون سج، بعنوان: الأسباب الفردية للجنوح "، 991 19، إستندت الدراسات السابقة لأسباب الجنوح إلى العلاقات بين

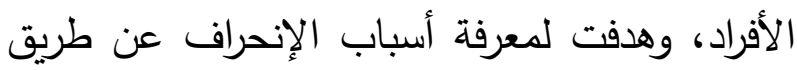

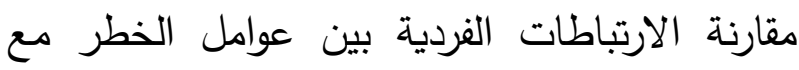

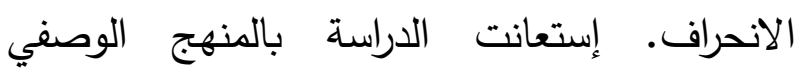
التحليلي الsقارن. وتكونت العينة من مجموعه 7. صبياً في أقدم عينة من دراسة بيتسبرغ الثباب

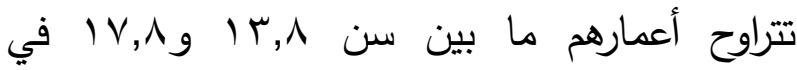
المتوسط. وقد توصلت الدراسة إلى مجموعة من النتائج من أهمها: أن الانحراف يحدث بسبب ضعف العلاقة بين الأبوين، ضعف الإشراف الأبوي، وتدني الوالدين

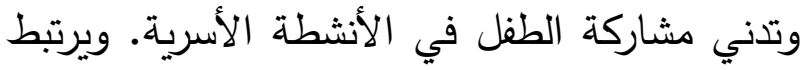

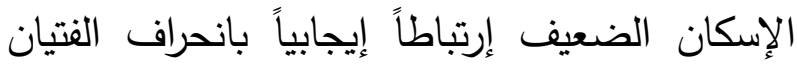

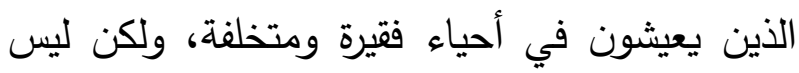

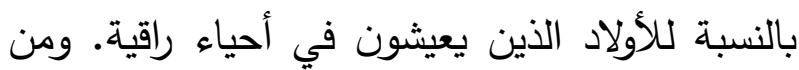

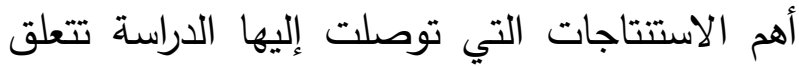
بالارتباطات المتخلفة في إطار الفروق بين الأفراد 
في كتابه " تقسيم العمل الاجتماعى"، وهو ما يعبر

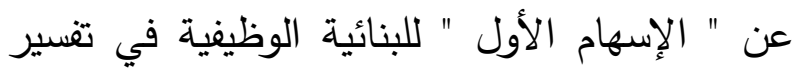
الإنحراف، في حين يتمثل "الإسهام الثانى" في تفسير الإنهانه

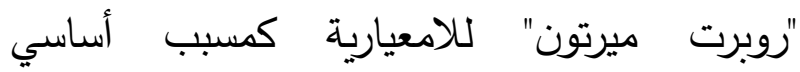
للإنحراف، حيث يعرّفها بأنها "تعبر عن انهيار القيم

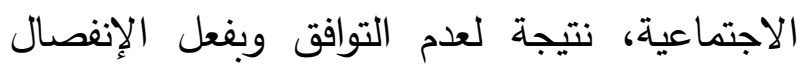

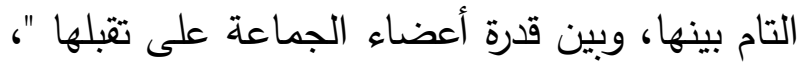

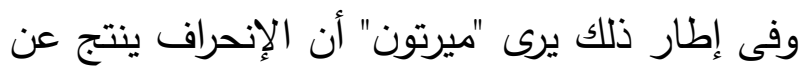
عدم الترابط بين الأهداف، والغايات الثقافية التي لتئي

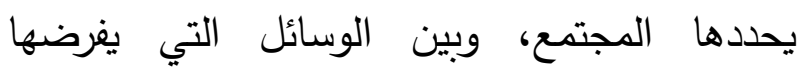
المجتمع لتحقيق ذلك (--: Robert merton,1968). هذا ويأتي " الإسهام الثالث " للبنائية الوظيفية في تفسير الجريمة، من خلال " تالكوت بارسونز " عبر الإنهام

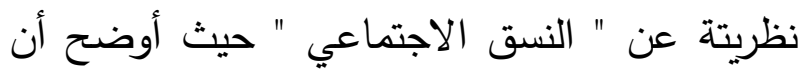

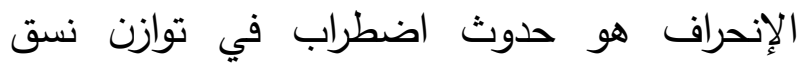
التفاعل المستقر نتاج للتغير في بناء دوافع الفعل الاجتماعى لأعضاء النسق بفعل كبت حاجات غير

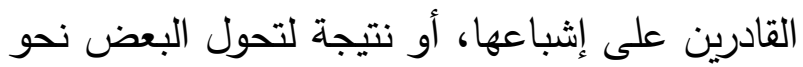
توجه ثقافى أخر مغاير، أو نقد النموذج القيمى القائم

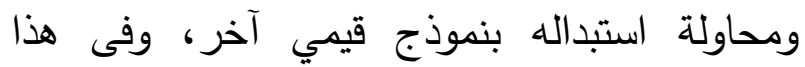

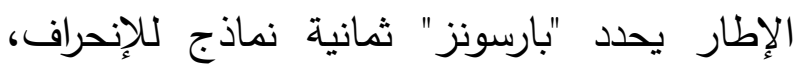
وهى: - السيطرة: وتحدث عندما يكون العنصر الإمتثالى

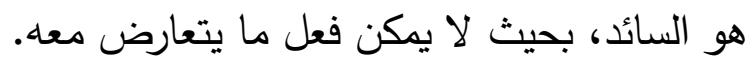

إليها تلك الدراسات مع نتائج الدراسة الراهنة، وذلك بهدف الكثف عن أوجه الاتفاق والاختلاف على لهات كافة الأصعدة النظرية والمنهجية والميدانية. سابعاً: المدخل النظرى للدراسة: ثمة عدة مداخل نظرية إهتمت بتحليل، وتفسير أسباب، ومصادر السلوك الإنحرافى موضحة مدى لهی أهمية الدور الذي تقوم به مؤسسات التتشئة

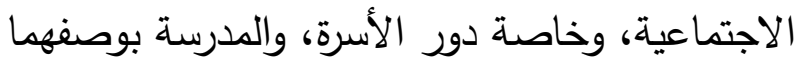

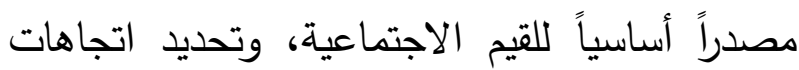
الأفراد السلوكية، وبناء الثخصية، وفقاً وطبيعة الدور التزبوى، والقيمى الذي تهدف إليه تلك المؤسسات وتسعى لغرسه لدى أفراد المجتمع، وصولاً

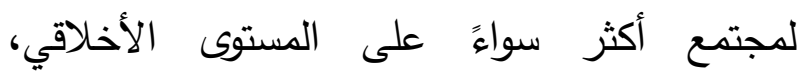

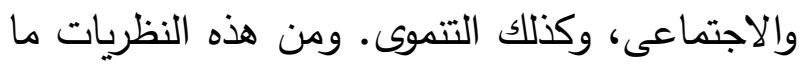
أولاً: البنائية الوظيفية وتقسير السلوك الإنحرافى

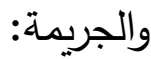
تعد البنائية الوظيفية إحدى النظريات الاجتماعية التي اهتمت بتفسير السلوك الإنحرافى، والجريمة، وذلك من خلال مفهوم " اللامعيارية" الذى تحدث

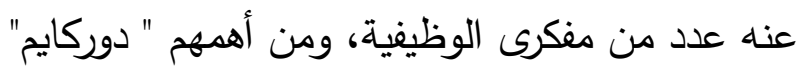
حيث قدم تعريفاً واضحاً، ودقيقاً لها يتمثل في أنها تعبر عن حالة من الإضطراب تصيب النظام، أو حالة من التسيب، وانعدام الإنتظام نتيجة عدد من

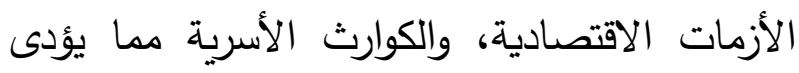
إلى الإنحراف، والجريمة، وهو ما أكد عليه "دوركايم" الاستهات 
- هناك علاقة وظيفية قوية بين كل من السلوك،

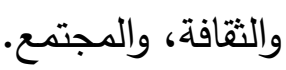
- أن كل نسق اجتماعى يتضمن عدد من الآليات، والضوابط غير المخططة، تهدف إلى مواجهة السلوكيات، والميول الانحرافية - أن الميل للسلوك المنحرف، أو الإلتزام بالضوابط، والقوانين الاجتماعية يعتمد على مضمون ما قد اكتسبه الفرد من قيم، وسلوكيات، ومعايير من خلال

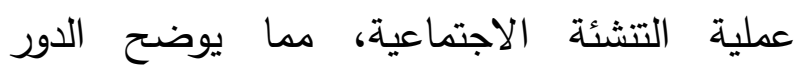
المحورى للأسرة، والمدرسة كأولى مؤسسات التتشئة الاجتماعية، والقائم الأول بها. - إن الميل للإنحراف لا يتم بصورة عشوائية، ولكنه

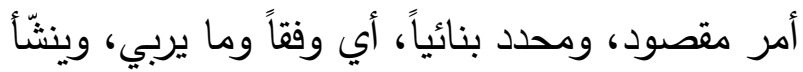
عليه الأفراد، إضافة إلى طبيعة ما ينقل للفرد من خلال المجتمع، ومؤسساته المختلفة. - يتأثر ميل الفرد للإنحراف بالفرص المونساته الموضوعية

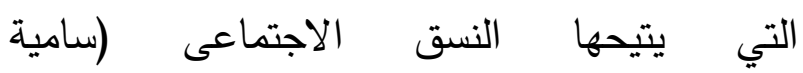
الساعاتى، 919 ( ). ثانياً: نظرية "ريس" Reiss والسلوك الإنحرافى: ترى هذه النظرية أن السلوك الإنحرافى(الجريمة)

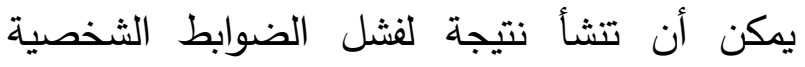
الاجتماعية في جعل السلوك أوالفعل الاجتماعى لهني

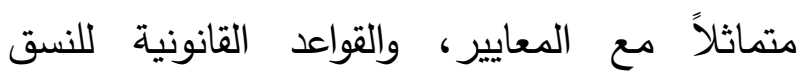
الاجتماعي، ومن مصادر الضبط الاجتماعى التي تقى المجتمع من الإنحراف، وتحول دون انتشار

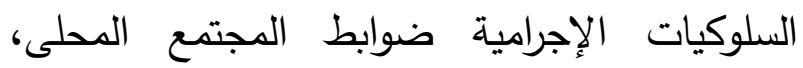

- الإذعان: ويشير إلى وجود العنصر الإمتثالى،

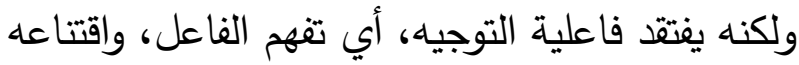

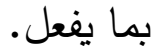
- العدوانية: وهو توجيه انحرافى بفعل الثعور بالاغتراب عما هو سائد قيمياً، واجتماعياً. - الإنفعال القهرى: وهو توجيه يتميز بغلبة المكون الاغترابى دون الإتجاه للعدوانية، حيث نجد أن حالته المتطرفة تتمثل في الإنعزالية. - الفرض القهرى للمعيار: ويشير إلى التوجيه الانحرافى الذي ينتج عن الإرتباط بين التوجه

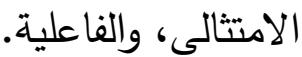
- التعلق الكمالى بالطقوس: وهو الحاجة عند التوجيه الامتثالى، ولكن مع انعدام الفاعلية تجاه

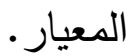
- المراوغة: وتحدث عندما يكون المكون الاغترابى هو السائد، حيث يكون نموذجه فاعلاً، مما يدفعه إلى السخرية من القوانين لمجرد كونها قوانين. - الانسحاب: وهو يعبر عن ارتباط المكون الاغترابي بالنموذج غير الفاعلى، حيث تتمثل في تحاشى المواقف التي قد تعرض فاعلها للجزاءات. في إطار ما سبق طرحه أكد "بارسونز" على عدة

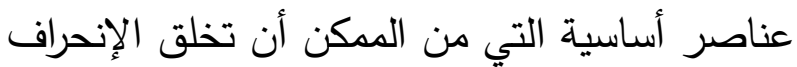
بالمجتمع، من خلال طبيعة العلاقة بين التوجيهات

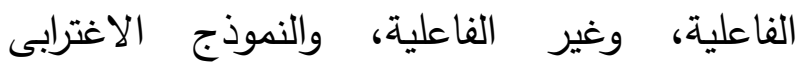

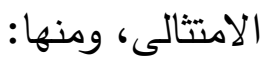


ضعف مؤسسات التشئة الاجتماعية، خاصة القائمة بالضبط الاجتماعى، والسلوكى للأفراد، مما ينتج عنه عدم احترام القوانين الاجتماعية، والخروج عليها، وعدم الإلتزام بها كآلية أساسية لضبط الأفراد اجتماعياً، وسلوكياً. وفى هذا الإطار تؤكد هذه النظرية على أن الإلتزام بالمدرسة يمنع السلوك الجانح، وفقاً وما تشير إليه العناصر التي تنطوى عليها تلك النظريـة، ومنها: - يتعلم أفراد المجتمع السلوك النظامى عن طريق التفاعل الاجتماعى، وششكل أكثر فاعلية من مرن التعرض للتجربة، والخطأ في الحياة الاجتماعية، مما يبرهن مدى أهمية التفاعل الذي تخلقه مؤسسات الضبط والتتشئة الاجتماعية، وخاصة الأسرة، والمدرسة. - الفرد الذى يرتكب الجريمة، ويمارس السلوك الإنحرافى لا تتقصه الأخلاق، ولكن لديه أخلاقيات مختلفة، كون الفرد لا يولد بالفطرة مجرم، حيث لا يعرف شيء عن السلوك السوى، وغير السوى، ومن ثم، فالسلوك الإنحرافى يُكتسب وليس بالفطرة. - يتم ضبط الجريمة جزئياً، لأن الناس لا يؤذون من يحبونهم، ولا يخاطرون في فقدان سمعتهم، ومكانتهم. - لا يلتزم الأفراد دائماً بالقانون، وكذلك لا يخرقونه دائماً.

- يميل الناس إلى الجريمة، أو الابتعاد عنها، والالتزام بالقانون، ومن خصائص الملتزمين بالقانون ما يلى
والضوابط النظامية التي تتضمن الجيرة، ومناطق الإقامة، بالإضافة إلى المدرسة التي تعد أبرز مصادر الضبط الاجتماعى من حيث التأثير، ولا يمكن إغفال دور الأسرة أولى مؤسسات التشئة الاجتماعية، والقائم الأول بالضبط الاجتماعى، والسلوكى للأفراد كونها الجماعة الأولية، غير Frazier , 1976 ( الرسمية في تشكيل شخصية الفرد. - : ) مقد أوضح "Reiss" عدة حالات يمكن أن تصبح في إطارها الضوابط غير الفعّالة مصدراً لإنحراف، ومنها: - غياب المعايير السلوكية، والقواعد الاجتماعية لدى الجماعات المرجعية الهامة (الأسرة، المدرسة،). - إنهيار الضوابط الاجتماعية التي كانت راسخة في مراحل سابقة. - عندما لا يستطيع الفرد التكيف، مع طبيعة معايير الضبط الاجتماعى المتعارف عليها مجتمعياً. - التناقض فيما بين القواعد الاجتماعية للى ل الجماعات المرجعية السابق الإشارة لها، مما يؤدى إلى خلى حالة من التخبط الاجتماعى أو اللامعيارية، وهي إحدى أسباب الإنحراف، والجريمة بالمجتمع.( مصلح الصالح،ء . . ب: 1 . 1-0. • ). ثالثاً: نظريـة الضبط الاجتماعى "لهيرشي" Hirsch

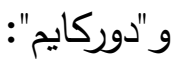
حيث يوضت "Hirsch" " من خلال نظرية الضبط الاجتماعى العوامل التي تحفز على الإنحراف السلوكى، والجريمة، وهو ما يمكن تلخيصه في 
تمارسه من رقابة، وتربية اجتماعية تجاههم، أي أن الأسرة من خلال نظرية دوركايم المؤسسة التي تكسب الفرد قواعد، وضوابط أخلاقية من شأنها بناء

$$
\text { المجتمع (مصلح الصالح، ع . . ب : ( . ) ). }
$$

نستتتج من التحليلات النظرية السابقة أن

النظريات الثلاثة يمكن الإفادة من مقولاتها في تفنير

مشكلة الدراسة، والتي تتمثل في دور مؤسسات

التشئة الاجتماعية، وبخاصة مؤسستي الأسرة

والمدرسة في الوقاية من الجريمة، حيث يمكن إعتبار

الأسرة و والمدرسة نسقين فرعيين داخل البنية

الاجتماعية بصورة عامة، فالأسرة تمثل نسقاً

إجتماعياً فرعياً داخل البنية الاجتماعية تتحدد أهم

وظائفها في التنشئة الاجتماعية وتربية الأبناء على القيم الاجتماعية الإيجابية التي تمثل حصناً لهم يحول دون وقوعهم في السلوك الاجرامي بأنماطه وأشكاله المختلفة. ومن جانب آخر، فالمدرسة كذلك تمثل نسقاً فرعياً داخل النظام التربوي، والذي يُعد هو الآخر من أهم النظم الاجتماعية التي تؤدي عدداً من الوظائف يتمثل أهمها في التربية والتعليم، حيث أن من أهم وظائفها نقل الموروثات الثقافية وتعليمها للجيال، وذلك للاستفادة منها في حياتهم اليومية، كما أنها في الوقت ذاته تُمكن السباب من الانفتاح على الثقافات الأخرى والإفادة من تلك الثقافات في نمو شخصياتهم ومستوى وعيهم الاجتماعي والثقافي. ومن ثم، فإن قيام هاتين المؤسستين بوظائفهما في عملية التشئة الاجتماعية والتربوية، يؤدي إلى
- فيما يتعلق بطبيعة الروابط والعلاقات الاجتماعية مع الأخرين نجدها قوية، وفعّالة، مما يحول دون ارتكاب الجريمة، والإنحراف، ومن أقوى هذه الروابط ما يتكون في إطار الأسرة، إضافة إلى من بيدهم السلطة داخل المدرسة كالمدرسين، والموظفين، والعلاقات الشخصية الأخرى. - التعهدات، والالتزامات: وتشير إلى الإستثمارات الاجتماعية التي يقوم بها الفرد تجاه الآخرين كالزوجة، والأبناء، التعليم، والوظيفة، والإستثمارات المالية، واستثمارات الملكية، وكلما كانت تلك الإستثمارات مهمة للفرد، كانت فرصة ارتكاب الجريمة أقل. - معتقدات الفرد، ومدى تمسكه بها، والحفاظ عليها، تعتبر من أهم العوامل التي تحول دون ارتكاب الجريمة، والانحراف. (Hirsch , 1969). ومن ناحية أخرى يوضح إميل دوركايم في نظريتة عن الضبط الاجتماعى أن الأفراد عندما لا يحترمون السلطة الأخلاقية للمجتمع، أوعندما لا لإليكال

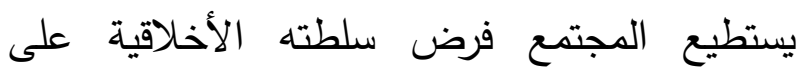
سلوكيات أفراده، فإنهم ينتهجون سلوكاً اجتماعياً غير سوياً وفق شهواتهم، ومصالحهم الشخصية، مدا يؤدى إلى العنف، والإنحراف ويهيئ الفرصة لإنتشار الجريمة. ويرى دوركايم أن الأسرة تعد بمثابة أقوى الآليات التي تدعم تتشئة الأفراد، وتربطهم بمجتمعاتهم، وتحفز لديهم السلوكيات الأخلاقية الإيجابية التي تتفق وضوابط المجتمع من خلا ما 
تعريفاً واضحاً، وعرض صحيفة الاستبيان على

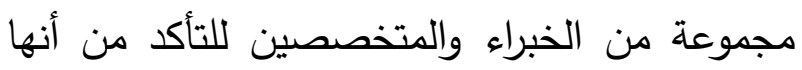
تقيس ما وضعت لقياساه، لذلك فقد تم عرض فن موضوع الدراسة والأهداف والتساؤلات وأداة الدراسة فئس

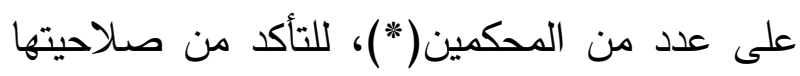
لقياس مختلف أبعاد مشكلة الدراسة، أما الثبات فيوضح أنه يمكن أن نكررعملية التحليل لنتائج الدراسة المبدئية لعدد معين من مفردات عينة الدراسة، قدرت ب •؛ مفردة ممثلة لعينة الدراسة الكلية، وقد تم الوصول إلى نتائج ثابتة فى كل مرة،

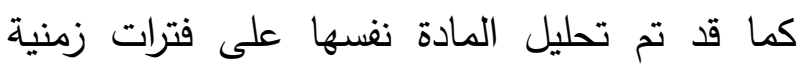
متباعدة، وقد كانت النتائج متفقة فى كل مرة مع النتائج فى المرات السابقة لها، ولم تتغير نتائج

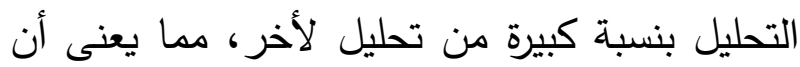
الأداة دقيقة ولا تحتاج إلى تعديلات. كما تم التطبيق على عينة عمدية ممثلة للشباب

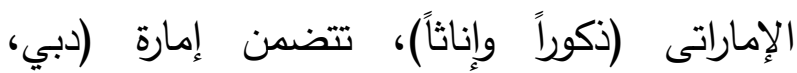

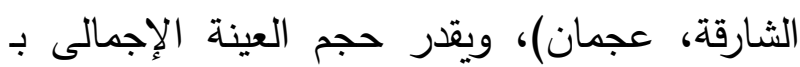

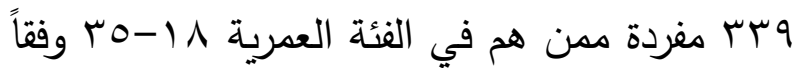
للتعريف الإجرائى لففهوم الثباب بالدراسة الراهنة. وقد تم اختيار العينة وفقاً لعدة مبررات من أههها: - اعتمدت الدراسة على عينة من الشباب لما لهذه

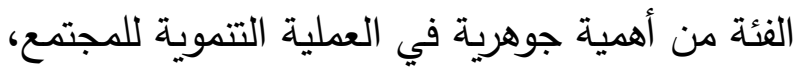
حيث تشير الأدبيات المختلفة إلى أن الشباب هم الثمانه

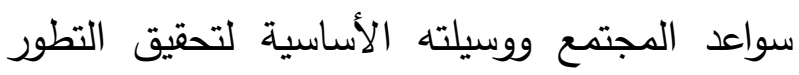
والإستقرار - مواع
تماسك المجتمع واستقراره وتوازنه، أما إذا حدث ما يسمي بالخلل الوظيفي، وذلك من خلال تراجع هاتين المؤسستين عن تحقيق وظائفهما بالثكل الذي ينبغي أن يكون، يحدث توتر وإضطراب وخلل على مستوى

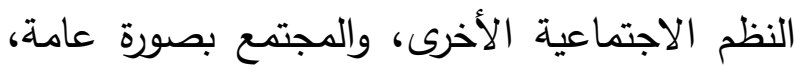

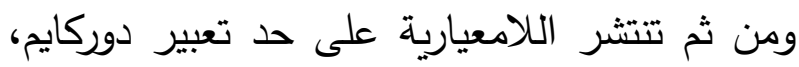
ويحدث تفكك وفوضى في المجتمع، ومن ثم تتنشر الجريمة والسلوك الانحرافي في ظل هذ الظروف. وهذا يعني أن هاتين المؤسستين إلى جانب مؤسسات أخرى كالمؤسسات الدينية والاعلامية والتثتيفية لهما دور كبير في الحفاظ على أمن المجتمع وسلامته

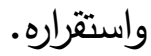
ثامناً: الإجراءات المنهجية للدراسة: تَعد الدراسة الحالية من الدراسات الوصفية التحليلية التي تحاول التعرف على أهمية ودور مؤسسات التنشئة الاجتماعية (الأسرة، والمدرسة) في الوقاية من الجريمة، من وجهة نظر الثباب (1/ (1) سنه)، وهو ما يمكن توضيحه واستنباطه من خلال

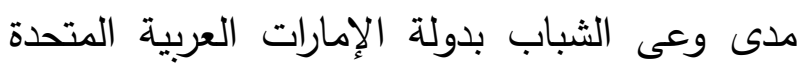

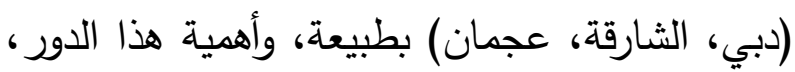
مما يستوجب الإعتماد على أداة صحيفة الاستبيان لجمع البيانات التي يمكن في إطارها ومن خلال استقراءها، وتحليلها تحقيق الهدف من الدراسة. هذا مع ضرورة الإيفاء بالصدق والثبات، ويقصد

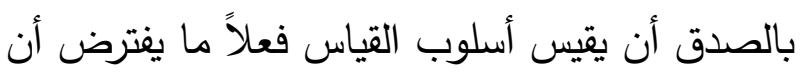
يقيسه، ويتم هذا بتحديد فئات التحليل بدقة وتعريفها 
كما تم الإعتماد على أسلوبين لتحليل بيانات الدراسة

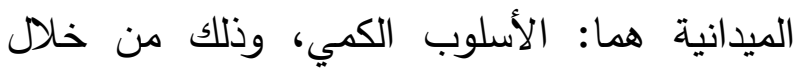
الجداول التكرارية البسيطة، والأسلوب الكيفي من خلال تحليل البيانات المتعلقة بمتغيرات الدراسة؛ وذلك باستخدام الرزمة الاحصائية للعلوم الاجتماعية (SPSS) للدراسة الميدانية والتى شملت مقاييس المتغيرات وهي مقايس الاهمية النسبية، مقياس الترتيب حسب الأهمية، ومقياس المتوسط الراجح (الانحدار المتعدد)

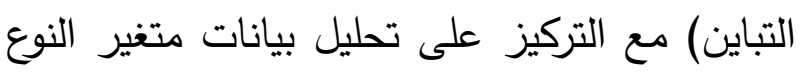
فى كل المقاييس. تاسعاً: - الدراسة الميدانية: أولاً: الخصائص الديموجرافية والاجتماعية ل لعينة

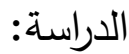
1- توزيع العينة وفقاً لمتغير النوع:

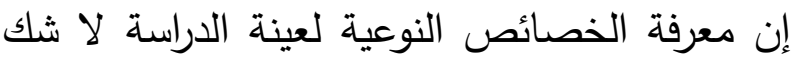
في أنه يمكن أن يفسر مدى الاختلاف أو الاتفاق في وجهات نظرهم فيما يتعلق بمتغيرات الدراسة. وقد كثفت بيانات الدراسة الميدانية أن عينة الدراسة موزعة بين الذكور والاناث على النحو الآتي: بلغ

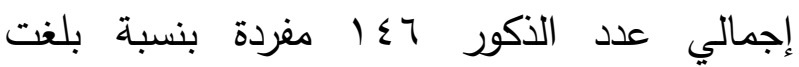

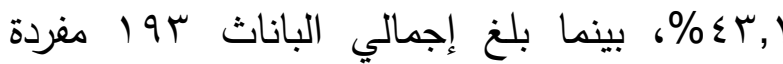
بنسبة بلغت 97,9\% من إجمالي العينة، وهذا يشير إلى زيادة عدد الإناث على عدد الذكور • والبيانات

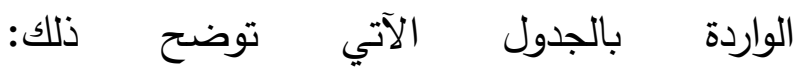

- تم اختيار دولة الإمارات العربية المتحدة كمجتمع للدراسة، وذلك كونها من المجتمعات العربية التي تولى اهتماماً خاصاً بمؤسسات التنشئة الاجتماعية

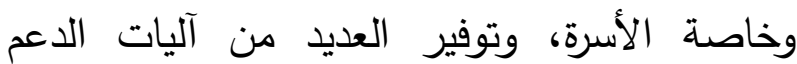
الاجتماعى، والاقتصادي، والنفسى، إضافة إلى الى

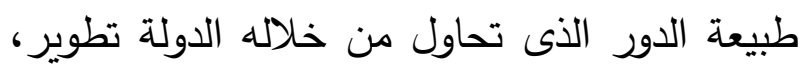
وتجويد العملية التعليمية، والنهوض بالوضع التربوى،

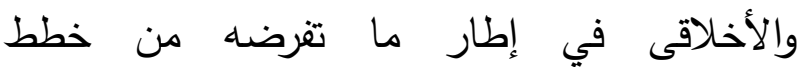

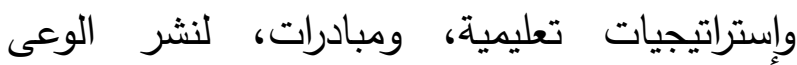
بأهمية دور المدرسة، وخاصة من الناحية التربوية والأخلاقية، وتقويم دور المدرسة في توجهها نحو المجتمع، وتحقيق أهدافه التتموية. - يحتوي مجتمع الدراسة الراهنة (دبى، الثارقة، عجمان) على أكبر الإمارات من حيث معدل الكثافة

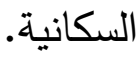
وقد إعتمدت الدراسة على أداة الاستبيان، حيث

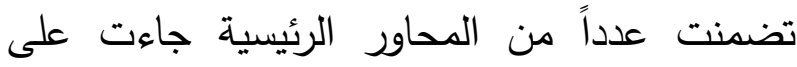
النحو الآتي: الخصائص الاجتماعية والديموجرافية لعينة الدراسة، دور الأسرة في الوقاية من الجريمة،

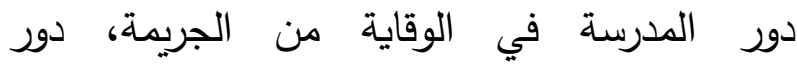

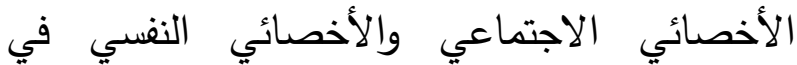
الوقاية من الجريمة، وأخيراً المعوقات التي تحول دون تفعيل دور كل من الأسرة والمدرسة في الوقاية

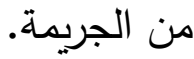




\section{جدول رقم (1) يوضح}

توزيع أفراد العينة حسب للنوع

\begin{tabular}{|c|c|c|}
\hline$\%$ & ك & النوع \\
\hline$\varepsilon r, 1$ & $1 \leqslant 7$ & ذكور \\
\hline 04,9 & 194 & إناث \\
\hline$\% 1 .$. & rrq & لمجموع \\
\hline
\end{tabular}

0ب سنة) حيث بلغت نسبة الذكور لهذه الفئة

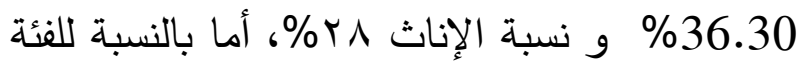
العمرية (أقل من 1/ 1 سنة) فقد مثلت أقل نسبة، حيث بلغت نسبة الذكور 4.1\% ونسبة الاناث 1.6\%. ويمكن الكشف عن ذلك من البيانات

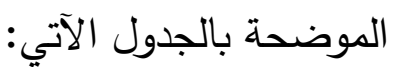

r- توزيع أفراد العينة وفقاً لمتغير العمر والنوع:

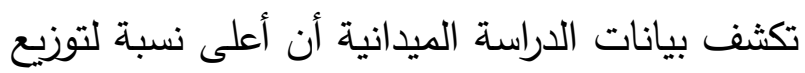

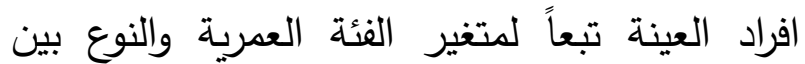

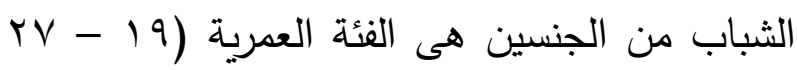

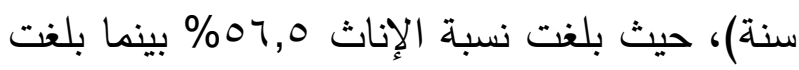

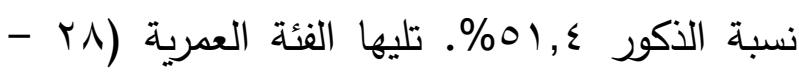

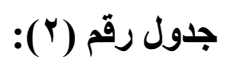

توزيع افراد العينة تبعاً لمتغير الفئة العمرية

\begin{tabular}{|c|c|c|c|}
\hline \multicolumn{2}{|c|}{ النوع } & & \multirow{2}{*}{ الفئة العمرية } \\
\hline أنثى & ذكر & & \\
\hline 3 & 6 & النكرار & \multirow{2}{*}{ أقل من ^/ سنة } \\
\hline 1.60 & 4.10 & النسبة المئوية \% & \\
\hline 109 & 75 & التكرار & \multirow{2}{*}{ بين 19 - Y سنة } \\
\hline 56.50 & 51.40 & النسبة المئوية \% & \\
\hline 54 & 53 & النكرار & \multirow{2}{*}{ بين ^r ـ ـ T سنة } \\
\hline 28.00 & 36.30 & النسبة النئوية \% & \\
\hline 27 & 12 & التكرار & \multirow{2}{*}{ كثر من مr سنة } \\
\hline 14.00 & 8.20 & النسبة المئوية \% & \\
\hline 193 & 146 & النكرار & المجموع \\
\hline
\end{tabular}

ب- توزيع أفراد العينة وفقاً لمتغير المستوى التعليمي: للمبحوثين، وهو الأمر الذي ينعكس على آرائهم

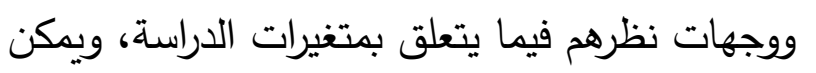
لا شك في أن معرفة المستويات التعليمية لعينتي لوني الكثف عن مدى التباين والتتوع في المستويات الدراسة الذكور والاناث، ومعرفة مدى التباين والتتوع

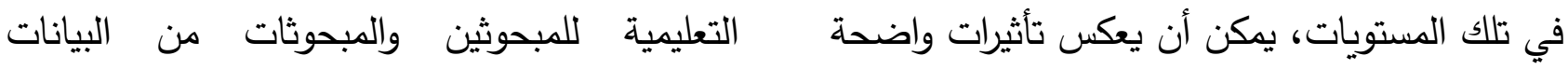
على مستوى الوعي الاجتماعي والمعرفي والثقافي الموضحة بالجدول الآتي: 


\section{جدول رقم (广) يوضح}

توزيع افراد العينة تبعاً لمتغير المستوى التعليمى رلئ

\begin{tabular}{|c|c|c|c|c|}
\hline \multirow{2}{*}{ الإجمالي } & \multicolumn{2}{|c|}{ النوع } & & \multirow{2}{*}{ المستوى التعليمي } \\
\hline & ذكر & أنثى & & \\
\hline 217 & 67 & 150 & التكر ار & \multirow{2}{*}{ جامعي } \\
\hline 64.01 & 19.76 & 77.70 & النسبة المئوية \% & \\
\hline 82 & 57 & 25 & الت التكر ار & \multirow{2}{*}{ 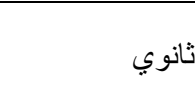 } \\
\hline 24.18 & 16.81 & 13.00 & النسبة المئوية \% & \\
\hline 26 & 8 & 18 & التكرار & \multirow{2}{*}{ جامعي فما فوق } \\
\hline 7.66 & 2.39 & 9.30 & النسبة المئوية \% & \\
\hline 14 & 14 & 0 & التكر ار & \multirow{2}{*}{ إعدادي } \\
\hline 4.12 & 4.12 & 0,00 & النسبة المئوية \% & \\
\hline 339 & 146 & 193 & التكر ار & \multirow{2}{*}{ لإجمالي } \\
\hline 100 & 100 & 100 & النسبة المئوية \% & \\
\hline
\end{tabular}

ونسبة الذكور 4.12\% بينما لم توجد لمستوى التعليم الإعدادي نسبة في فئة الإناث. ع - توزيـع أفراد العينة وفقاً لمتغير مكان الاقامة: تكثف بيانات الدراسة الميدانية فيما يتعلق بتوزيع افراد العينة تبعاً لمتغير مكان الإقامة أن أعلى نسبة

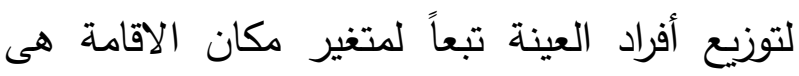

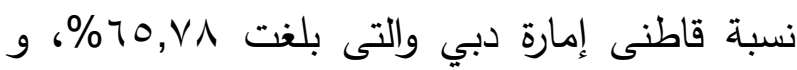
\%VV,V من حيث النوع فإن نسبة الإناث بلغت أعلي من نسبة الذكور •\% . ت تليها نسبة الأفراد قاطنى إمارة الشارقة وهي r Y, r F \%، وجاءت نسبة الذكور rv,V أعلي من نسبة الإناث ع,. ( \% . أما أدني نسبة فهي نسبة قاطنى إمارة عجمان من أفراد

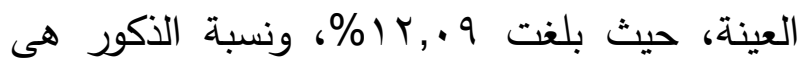

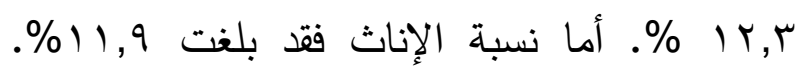
ويتضح ذلك من البيانات الواردة بالجدول الآتي:
تكثف البيانات الموضحة بالجدول السابق والتي تتعلق بتوزيع أفراد العينة تبعاً لمتغير المستوى التعليمى أن أعلى نسبة لتوزيع أفراد العينة تبعاً

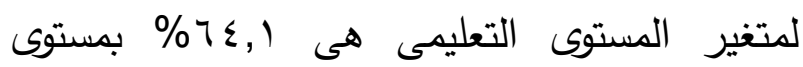
التعليم الجامعى. ومن حيث توزيع النسب وفقاً للنوع، فقد بلغت نسبة الإناث لهذا المستوى التعليمى \% وهي أعلي نسبة عن نسبة الذكور، حيث بلغت نسبة الذكور 19,V 1 \% . أما بالنسبة للمستوى

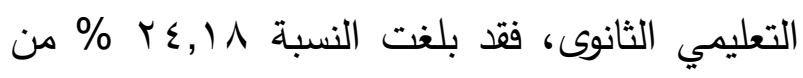
مجموع أفراد العينة. ونسبة الذك ور (1, ا I \% أعلي من نسبة الإناث باث\%. أما بالنسبة لمستوى التعليم

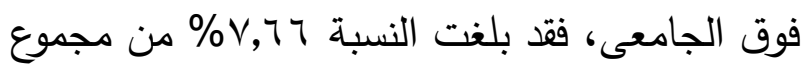
أفراد العينة. ونسبة الذكور 2.39 \% ونسبة الإناث

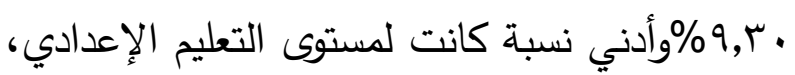
فقد بلغت النسبة ب ا,§\% من مجموع أفراد العينة. 
جدول رقم (4) يوضح

توزيع أفراد العينة تبعاً لمتغير مكان الإقامة

\begin{tabular}{|c|c|c|c|c|}
\hline \multirow{2}{*}{ الإجمالي } & \multicolumn{2}{|c|}{ النوع } & & \multirow{2}{*}{ مكان الإقامة } \\
\hline & ذكر & أنثى & & \\
\hline 223 & 150 & 73 & التكر ار & \multirow{2}{*}{ دبي } \\
\hline 65.78 & 77.70 & 50.00 & النسبة المئوية \% & \\
\hline 75 & 20 & 55 & التكر ار & \multirow{2}{*}{ الثنارقة } \\
\hline 22.12 & 10.40 & 37.70 & النسبة المئوية \% & \\
\hline 41 & 23 & 18 & التكر ار & \multirow{2}{*}{ عجمان } \\
\hline 12.09 & 11.90 & 12.30 & النسبة المئوية \% & \\
\hline 339 & 193 & 146 & التكر ار & \multirow{2}{*}{ الإجمالي } \\
\hline 100 & 100 & 100 & النسبة المئوية \% & \\
\hline
\end{tabular}

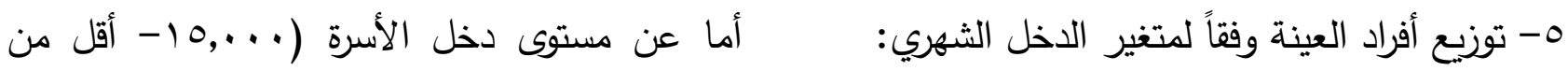

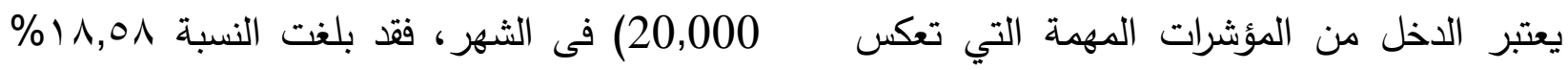
المستوى الاقتصادي لعينة الدراسة، والذي يكون له من مجموع أفراد العينة، حيث بلغت لهنت نسبة الذكور أكبر الأثر في تحديد الظروف المعيشية وأنماط 15.50\% بينما بلغت نسبة الإناث 22.00 \% الحياة والمعيشة. وتعكس بيانات الدراسة الميدانية وهي أعلي من نسبة الذكور . وبالنسبة لمستوى دخل

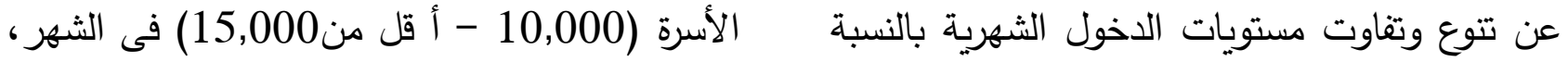
لعينتي الدراسة من الذكور والإناث بصورة عامة، فقد بلغت نسبة 20.35 \%من مجموع أفراد العينة،

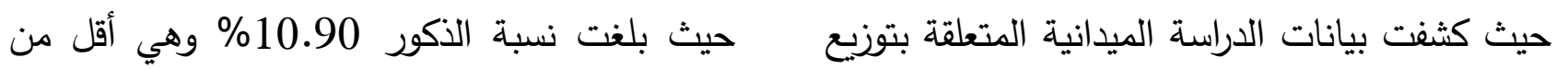

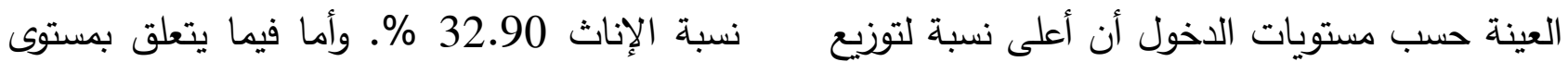

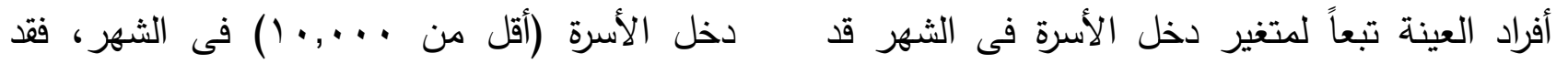
بلغت النسبة 9,7§\% من مجموع أفراد العينة والتى بلغت النسبة 14.15 \%من مجموع أفراد العينة،

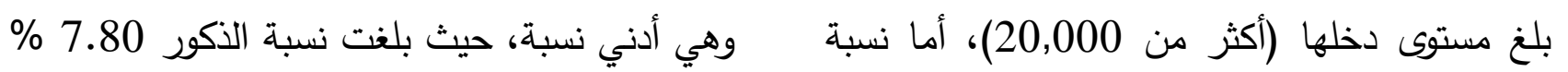

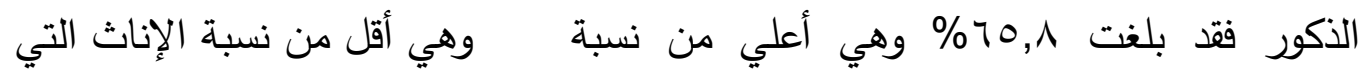
بلغت 22.60 \% م ـ ويمكن توضيح ذلك من البيانات الإناث والتي بلغت 9 r. 


\section{جدول رقم (•)يوضح}

توزيع افراد العينة تبعاً لمتغير الدخل الثهري للأسرة

\begin{tabular}{|c|c|c|c|c|}
\hline \multirow{2}{*}{ ال الإجمالي } & \multicolumn{2}{|c|}{ النوع } & & \multirow{2}{*}{ خخل الأسرة فى الثهر/در هم } \\
\hline & ذكر & أنثى & & \\
\hline 48 & 15 & 33 & التكرار & \multirow[t]{2}{*}{ 10,000 أقل من } \\
\hline 14.15 & 7.80 & 22.60 & النسبة المئوية \% & \\
\hline 69 & 21 & 48 & التكر ار & \multirow{2}{*}{ 10,000 ـأ قل من 15,000 } \\
\hline 20.35 & 10.90 & 32.90 & النسبة المئوية \% & \\
\hline 63 & 30 & 33 & التكر ار & \multirow{2}{*}{ ـ . . 1 ـ أقل من 20,000 } \\
\hline 18.58 & 15.50 & 22.00 & النسبة المئوية \% & \\
\hline 159 & 127 & 32 & التكرار & \multirow{2}{*}{ أكثر من 20,000 } \\
\hline 46.90 & 65.80 & 21.90 & النسبة المئوية \% & \\
\hline 339 & 193 & 146 & التكرار & \multirow{2}{*}{ ل الإجمالي } \\
\hline 100 & 100 & 100 & النسبة المئوية \% & \\
\hline
\end{tabular}

الإناث 20.50\%.وبالنسبة لمستوى التعليم الإعدادى، فقد بلغت النسبة ץr, • ا \% من مجموع أفراد العينة. وقد بلغت نسبة الذكور 5.20\% ونسبة

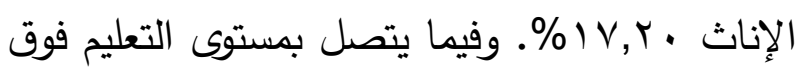
الجامعى، فقد بلغت النسبة 8.28 \% من مجموع أفراد العينة. وقد بلغت نسبة الذكور 7.30 \% ونسبة الإناث 9.60 \% . أما فيما يتعلق بمستوى التعليم الابتدائى، فقد بلغت النسبة 8.25\% من مجموع أفراد العينة. وقد بلغت نسبة الذكور 7.30\% ونسبة الإناث 60.60\%. ويتضح ذلك من البيانات المبينة بالجدول الآتي:
ج- توزيـع أفراد العينة وفقاً لمتغير المستوى التعليمي

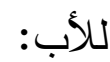

تكثف البيانات المتعلقة بتوزيع أفراد العينة تبعاً لمتغير المستوى التعليمى للأب أن أعلى نسبة لتوزيع أفراد العينة تبعاً لمتغير المستوى التعليمى للأب هى 58.40 بمستوى التعليم الجامعى. ومن حيث توزيع النسب وفقاً للنوع، فقد بلغت نسبة الإناث لهذا المستوى التعليمى 43.20\%، بينما بلغت نسبة الذكور 69.90 \%. أما بالنسبة لمستوى التعليم الثانوى، فقد بلغت النسبة 14.74 \% من مجموع أفراد العينة. وبلغت نسبة الذكور 10.40 \% ونسبة 


\section{جدول رقم (" )يوضح}

توزيع أفراد العينة تبعاً لمتغير المستوى التعليمى للأب

\begin{tabular}{|c|c|c|c|c|}
\hline \multirow{2}{*}{ الإجمالي } & \multicolumn{2}{|c|}{ النوع } & & \multirow{2}{*}{ المستوى التعليمي } \\
\hline & ذكر & أنثى & & \\
\hline 198 & 135 & 63 & التكر ار & \multirow{2}{*}{ جامعي } \\
\hline $58.40 \%$ & $69.90 \%$ & $43.20 \%$ & النسبة المئوية \% & \\
\hline 50 & 20 & 30 & التكر ار & \multirow{2}{*}{ ثانوي } \\
\hline $14.74 \%$ & $10.40 \%$ & $20.50 \%$ & النسبة المئوية \% & \\
\hline 35 & 10 & 25 & التكر ار & \multirow{2}{*}{ إعدادي } \\
\hline $10.32 \%$ & $5.20 \%$ & $17.20 \%$ & النسبة المئوية \% & \\
\hline 28 & 14 & 14 & التكر ار & \multirow{2}{*}{ جامعي فما فوق } \\
\hline $8.28 \%$ & $7.30 \%$ & $9.60 \%$ & النسبة المئوية \% & \\
\hline 28 & 14 & 14 & التكر ار & \multirow{2}{*}{ ابتدائي } \\
\hline $8.25 \%$ & $7.30 \%$ & $9.60 \%$ & النسبة المئوية \% & \\
\hline 339 & 146 & 193 & التكر ار & \multirow{2}{*}{ الإجمالي } \\
\hline $100 \%$ & $100 \%$ & $100 \%$ & النسبة المئوية \% & \\
\hline
\end{tabular}

V- توزيع أفراد العينة وفقاً لمتغير المستوى التعليمي נلأم:

مما لا شك فيه أن المستوى التعليمي للآباء ينعكس على المستوى الثقافي والمعرفي للأبناء، وذلك حيث يختلف أسلوب تنشئة الأبناء الذين يعيشون في ظل أسرة تضم آباء متعلمين ومثقفين عن أسلوب التشئية الذي يتم في أسرة تضم آباء غير متعلمين وغير مثقين، ومن ثم فالمناخ الاجتماعي والثقافي للأسرة يعكس تأثيرات مباشرة أو غير مباشرة على مستوى الوعي الاجتماعي والثقافي للأبناء. . ولقد كشفت بيانات الدراسة الميدانية الخاصة بالمستويات التعليمية لأمهات المبحوثين والمبحوثات أن أعلى نسبة لتوزيع أفراد العينة تبعاً لمتغير المستوى التعليمى للأم هى 54.86\% بمستوى التعليم
ومن حيث توزيع النسب وفقاً للنوع فقد بلغت نسبة الإناث لهذا المستوى التعليمى 37.70\%، بينما بلغت نسبة الذكور 67.90 \% أما بالنسبة لمستوى التعليم الثانوي، فقد بلغت النسبة 15.92\% من مجموع أفراد العينة. وبلغت نسبة الذكور 9.80\% ونسبة الإناث 24.00\%. وبالنسبة لمستوى التعليم فوق الجامعي، فقد بلغت النسبة 7.66 \% من مجموع أفراد العينة. وقد بلغت نسبة الذكور 8.30 \% ونسبة الإناث 6.80 \% . وفيما يتعلق بمستوى التعليم الإعدادي، فقد بلغت النسبة 12.09 \%من مجموع أفراد العينة. وقد بلغت نسبة الذكور 5.70\% ونسبة الإناث 20.50\%. أمابالنسبة لمستوى التعليم الابتدائي، فقد بلغت النسبة 9.43\% من مجموع أفراد العينة. ونسبة الذكور 8.30\% ونسبة الإناث \%11.00 
ووجهات نظرهم في متغيرات الدراسة. ويتضح ذلك وتشير البيانات السابقة إلى تتوع المستويات التعليمية

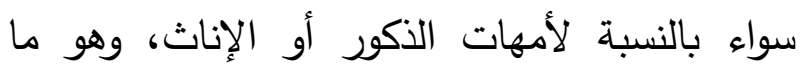
من البيانات الواردة بالجدول الآتي: يعني أن يكون هناك تأثيرات على آراء أفراد العينة وهوات هات

توزيع أفر اد العينة تبعاً لمتثفير المستوى التعليمى للأم

\begin{tabular}{|c|c|c|c|c|}
\hline \multirow{2}{*}{ الإجمالي } & \multicolumn{2}{|c|}{ النوع } & & \multirow{2}{*}{ المسنوى التعليمي } \\
\hline & ذكر & أنثى & & \\
\hline 186 & 131 & 55 & التكر ار & \multirow{2}{*}{ جامعي } \\
\hline 54.86 & 67.90 & 37.70 & النسبة المئوية \% & \\
\hline 54 & 19 & 35 & التكر ار & \multirow{2}{*}{ 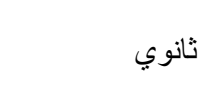 } \\
\hline 15.92 & 9.80 & 24.00 & النسبة المئوية \% & \\
\hline 41 & 11 & 30 & التكرار & \multirow{2}{*}{ إعدادي } \\
\hline 12.09 & 5.70 & 20.50 & النسبة المئوية \% & \\
\hline 32 & 16 & 16 & التكر ار & \multirow{2}{*}{ ابتدائي } \\
\hline 9.43 & 8.30 & 11.00 & النسبة المئوية \% & \\
\hline 26 & 16 & 10 & التكر ار & جامعي فما فوق \\
\hline 7.66 & 8.30 & 6.80 & النسبة المئوية \% & \\
\hline 339 & 146 & 193 & التكرار & \multirow{2}{*}{ الإجمالي } \\
\hline 100 & 100 & 100 & النسبة المئوية \% & \\
\hline
\end{tabular}

بالموافقة على العبارة نسبة 94.90 \% من الإناث

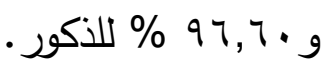

- أن 1, 19\% من مجموع أفراد العينة قد أجابوا بالموافقة على أهمية ترسيخ المعتقدات والممارسات

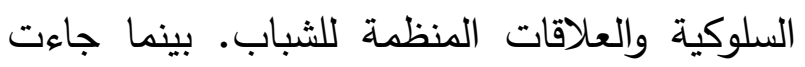

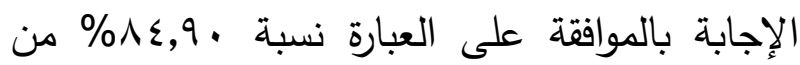

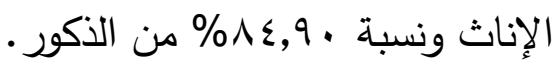

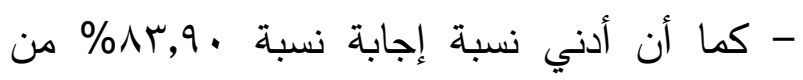

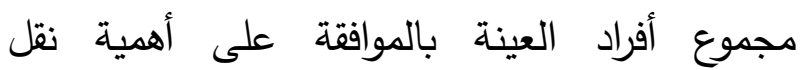
الموروثات الثقافية والاجتماعية من جيل لآخر • بينما

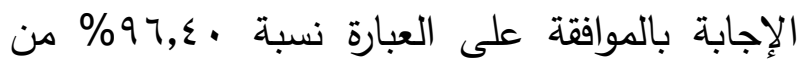

ثانياً: تحليل النتائج وفقاً لأهداف وتساؤلات الدراسة: أ- دور التتشئة الاجتماعية في مؤسستي الأسرة والمدرسة في الوقاية من الجريمة: تكثف التحليلات الاحصائية التي تعبر عن إستجابات عينة الدراسة فيما يتعلق بالأهمية النسبية والمتوسط المرجح لدور التتشئة الاجتماعية في لهئي

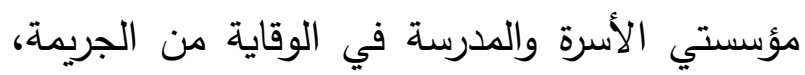
حيث جاءت نتائج التحليل كما يلي: - أن أعلي نسبة 96.30 \% توفير طرق وأساليب لحل المشاكل التي تواجهه الثباب. بينما الإجابة 


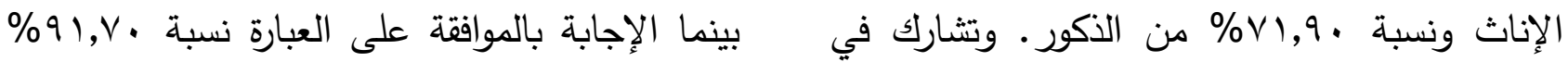

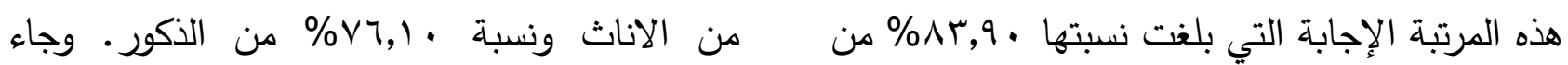
مجموع أفراد العينة بالموافقة على أهمية الترابط المتوسط المرجع عالياً بما يعادل س,ء. وتكثف والتكامل مع مؤسسات التشئة الاجتماعية الأخرى. البيانات الموضحة بالجدول الآتي ذلك. جلول رقم (^) يوضح

الأهمية النسبية والمتوسط المرجح لدور التنشئة الاجتماعية

في مؤسستي الأسرة والمدرسة في الوقاية من الجريمة

\begin{tabular}{|c|c|c|c|c|}
\hline \multirow[t]{2}{*}{ 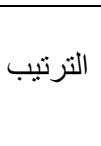 } & \multirow[t]{2}{*}{ الإجمالي } & \multicolumn{2}{|c|}{ النسبة المئوية للمو افقة (\%) } & \multirow[t]{2}{*}{ 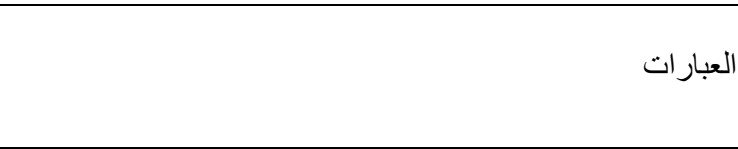 } \\
\hline & & إناث & ذكور & \\
\hline r & 91.15 & 84.90 & 84.90 & ترسيخ المعتقدات و الممارسات السلوكية و العلاقات المنظمة للثباب \\
\hline 3 & 83.90 & 96.40 & 71.90 & نقل الموروثات الثقافية و الاجتماعية من جيل لأخر \\
\hline 1 & 96.30 & 94.90 & 96.60 & توفير طرق و أساليب لحل المشاكل التي تواجهه الثباب \\
\hline 3 & 83.90 & 91.70 & 76.10 & الترابطو التكامل مع مؤسسات التنشئة الاجتماعية الأخرى \\
\hline & & 4.3 & & المنوسط المرجح \\
\hline
\end{tabular}

- بلغت نسبة الإجابة 9,V 9 \% من مجموع أفراد العينة بالموافقة على أن إلمام الوالدين بأسس التربية السليمة يسهم فى إبعاد الثباب عن الجريمة. وقد

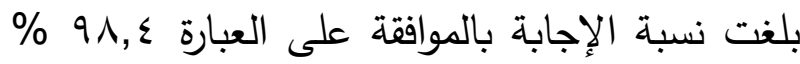
بالنسبة للإناث ونسبة 94.6 \% للذكور . - أما نسبة 92.91 \% من مجموع أفراد العينة قد أجابوا بالموافقة على أن مراقبة الأهل لسلوكيات الأبناء اليومية يُعد أمراً هاماً لتقليل فرصة ارتكابهم للسلوك الإجرامي. بينما جاءت الإجابة بالموافقة على العبارة نسبة 96.8 \% من جانب الإناث ونسبة 87.6 \% من جانب الذكور .
ب - دور الأسرة في الوقاية من الجريمة: تكثف التحليلات الاحصائية التي تعبر عن استجابات المبحوثين عينة الدراسة فيما يتعلق بدور الأسرة في الوقاية من الجريمة عن مجموعة من النتائج نجملها فيما يأتي: - أن أعلي نسبة كانت نسبة 100 \% من مجموع أفراد العينة قد أجابوا بالموافقة على أن استقرار الأسرة قد يقلل من إنخراط الشباب فى الجريمة. وقد جاءت نسبة الإجابة بالموافقة على العبارة متساوية بين الذكور والإناث، وقد بلغت 100 \% لكل 
بلغت نسبة الموافقة على العبارة 96.4 \% من جانب الإناث، ونسبة الاستجابات بلغت 81.5 \% من

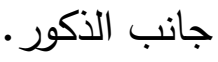
وهو ما يشير إلى أن ثمة إختلافات بين الذكور والإناث في وجهات نظرهم وآرائهم حول ما إذا كانت أساليب التتشئة الأسرية التي تعتمد على إلتات إتاحة

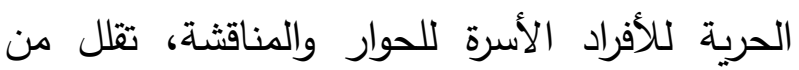
معدلات إرتكاب الجرائم، وقد جاءت تلك الفروق لصالح فئة الإناث. - ومن جانب آخر ، أوضحت البيانات والتحليلات

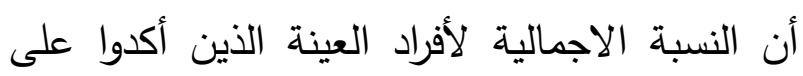
الموافقة على أن إلتزام الأسرة بالقيم الاجتماعية لألهائه

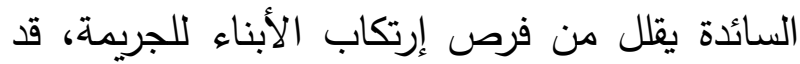
بلغت 89.37 \% من مجموع الاستجابات، وعلى لرع الرغم من ذلك، فثمة فروق واختلافات بين وجهات نظر الذكور والإناث حول هذه المتغير، فبينما جاءت نسبة الموافقة على العبارة 97.9 \% من لهن جانب الإناث، بلغت نسبة الموافقة على هذه العبارة 87 \% من جانب الذكورالذكور • ومن ثم، فالفروق

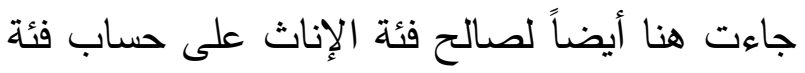
الذكور، مما يعني أن الإناث هن أكثر قدرة على لقاءلى تقدير المواقف وتقييمها من الذكور • لعن النان - كما بين النتائج أيضاً أن النسبة الاجمالية لاستجابات المبحوثين الذكور والإناث على المتغير المتعلق بالموافقة على أن إثراك الأبناء في القرارات

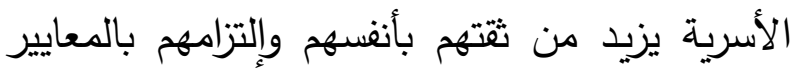

- وقد أجابت نسبة r.,Y Y \% من مجموع افراد العينة بالموافقة على أن إلتزام الأسرة بالقيم الدينية يعزز السلوك القويم للأبناء. حيث جاءت الإجابة بالموافقة على العبارة نسبة 97.9 \% من جانب الاناث ونسبة 84.2 \% من جانب الذكور . - وأجابت ما نسبته 91.4 \% من مجموع أفراد العينة بالموافقة على أن إرشاد وتوعية الأبناء يمثل ماتل

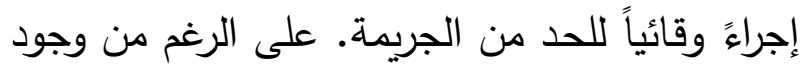
بعض الفروق بين نسبة إستجابات الذكور ونسبة

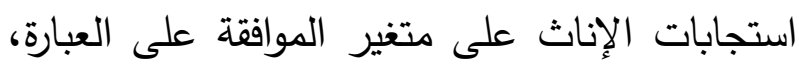
حيث بلغت النسبة 96.4 \% من جانب الإناث،

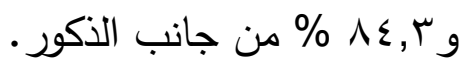
- وأجابت نسبة 91.1 \% من مجموع أفراد العينة

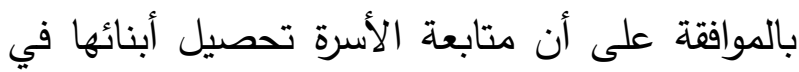

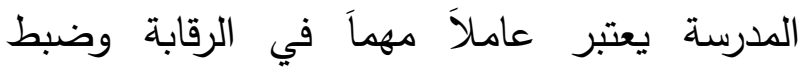
سلوكهم، وهي تعتبر أدني نسبة. وبينما بلغت نسبة الاستجابات بالموافقة على العبارة 91.1 \% من قبل لهبل الإناث، بلغت نسبة الاستجابات 83.5 \% من

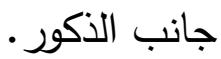
- كما أوضحت النتائج أيصاً أن النسبة الاجمالية

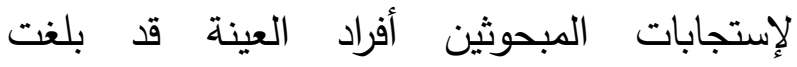
\%9.96 من مجموع الاستجابات فيما يتعلق بالمتغير الخاص بالموافقة على أن أساليب التنشئة

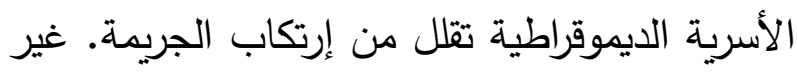
أن ثمة إختلافات بين نسب أستجابات المبحوثين

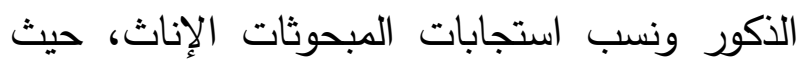


الاستجابات بالموافقة على العبارة 94.3 \% من جانب الإناث، لم تزد نسبة الاستجابات عن 76.8 \% من جانب الذكور.

- وقد أوضحت النتائج أيضاً أن نسبة 85.83 \% ماتبـ من مجموع أفراد العينة قد أجابوا بالموافقة على أن أن أنسة تواصل الوالدين مع المدرسة لمعرفة سلوك الأبناء يمثل إجراءً يقى الثباب من الجريمة. وثمة فروق لهن

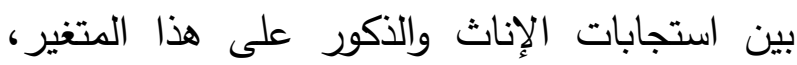
فبينما بلغت نسبة الاستجابات بالموافقة على العبارة 98 \% من جانب الإناث، لم تتجاوز نسبة الاستجابات على المتغير ذاته 69.8 \% من جانب

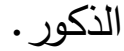

- وأخيراً تشير نتائج الدراسة إلى أن النسبة الاجمالية

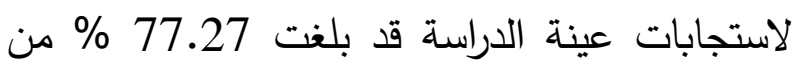

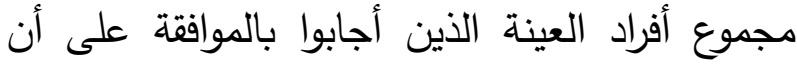

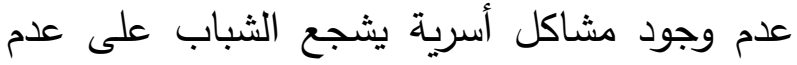
الاختلاط برفاق السوء. وعلى الرغم من ذلك، فقد جاءت النسب متباينة من حيث النوع، فبينما بلغت نسبة الاستجابات الخاصة بالموافقة على العبارة 95.3 \% من جانب الإناث، لم تتجاوز نسبة الاستجابات 65.8 \% من جانب الذكور. وقد بلغ المتوسط المرجح لدور الاسرة في الوقاية من الجريمة

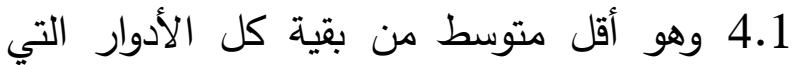
تسهم في الحد من الجريمة التي تتاولتها الدراسة بالتحليل في هذا الجزء. ويمكن الكثف عن ذلك من البيانات الموضحة بالجدول الآتي:
الاجتماعية، قد بلغت مش من مجموع الاستجابات. وبالرغم من ذلك، نجد فروق واختلافات واضحة بين نسب استجابات الإناث ونسب استجابات الذكور على هذا المتغير، فبينما بلغت نسبة الموافقة على العبارة 97,9 \% من جانب الإناث، بلغت نسبة استجابات الذكور على العبارة

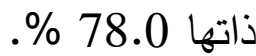
وهو الأمر الذي يؤكد أيضاً على أن الإناث أكثر

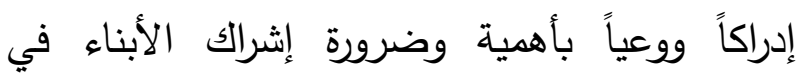
القرارات الأسرية، وأن هذا الإجراء يُزيد من ثقتهر بأنفسهم ويمنحهم القدرة على الالتزام بالمعايير والقيم الاجتماعية الايجابية، ومن ثم وقايتهم من الوقوع في الجريمة والأشكال المختلفة للسلوك الانحرافي. - وتأتي بعد ذلك النسبة الاجمالية لاستجابات المبحوثين 87.8 \% من أفراد العينة بالموافقة على العى لعابل

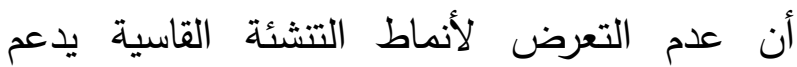
الثباب على الابتعاد عن بعض السلوكيات غير المقبولة اجتماعياً. وثمة اختلافات وتباينات في نسب لإبن استجابات كل من الإناث والذكور حول هذا المتغير، فبينما بلغت نسبة الموافقة على العبارة 95.4 \% من جانب الإناث، بلغت نسبة الاستجابات على المتغير ذاته 77.4 \% من جانب الذكور . - أجابت ما نسبته 86.72\% من مجموع أفراد العينة بالموافقة على أن سؤال الأسرة المتكرر عن من لهن

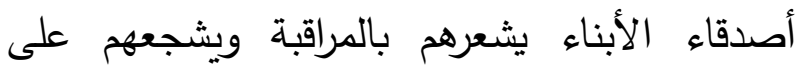
الإلتزام بمعايير السلوك القويم. فبينما بلغت نسبة 


\section{جدول رقم (9) يوضح}

\section{الأهمية النسبية والمتوسط المرجح لدور الأسرة في الوقاية من الجريمة}

\begin{tabular}{|c|c|c|c|c|}
\hline \multirow[t]{2}{*}{ الترتيب } & \multirow[t]{2}{*}{ الإجمالي } & \multicolumn{2}{|c|}{ النسبة المئوية للمو افقة } & \multirow[t]{2}{*}{ العبارات } \\
\hline & & إناث & ذكور & \\
\hline 1 & 100 & 100 & 100 & استقرار الأسرة قد يقلل من انخر اط الثباب فى الجريمة \\
\hline 2 & 96.7 & 98.4 & 94.6 & إلمام الو الدين بأسس التربية السليمة بسهم فى إبعاد الثباب عن الجريمة. \\
\hline 13 & 77.27 & 95.3 & 65.8 & عدم وجود مشاكل أسرية يشجع الثباب على عدم الاختلاط برفاق السوء. \\
\hline 10 & 87.8 & 95.4 & 77.4 & غير المقبولة اجتماعياً التنشئة القاسية يدعم الثباب على الابتعاد عن بعض السلوكيات \\
\hline 7 & 89.96 & 96.4 & 81.5 & أساليب التتشئة الأسرية الديموقر اطية تقلل من ارتكاب الجريمة. \\
\hline 3 & 92.91 & 96.8 & 87.6 & الاجرامي. الأهل لسلوكيات الأبناء اليومية يُعد أمراً هـاماً لتقليل فرصة ارتكابهم للسلوك \\
\hline 12 & 85.83 & 98 & 69.8 & الجريمة. الو الدين مع المدرسة لمعرفة سلوك الأبناء يمثل إجراءً يقى الثباب من \\
\hline 11 & 86.72 & 94.3 & 76.8 & بمعأير الأسلوة المتكرر عن أصدقاء الابناء بشعر هم بالمر اقبة ويشجعهم على الالتزام \\
\hline 8 & 89.37 & 97.9 & 87 & التزام الأسرة بالقيم الاجتماعية السائدة بقلل من فرصة الأبناء في ارتكاب الجريمة. \\
\hline 4 & 92.03 & 97.9 & 84.2 & التزام الأسرة بالقيم الدينية يعزز السلوك القويم للأبناء. \\
\hline 5 & 91.4 & 96.4 & 84.3 & إرشاد وتوعية الأبناء إجراء وقائي للحد من الجريمة. \\
\hline 9 & 88.73 & 96.9 & 78 & الاجتماعية. الأبناء في القرارات الأسرية يزيد من ثقتهم بأنفسهم والتزامهح بالمعايير \\
\hline 6 & 91.1 & 91.1 & 83.5 & سلوكهة. \\
\hline & & 4.1 & & المتوسط المرجح \\
\hline
\end{tabular}

الطفل وتربيته على القيم الايجابية وأنماط السلوك التي تتفق والقيم الاجتماعية العامة والمتفق عليها من قبل المجتمع. ويمكننا توضيح ذلك من خلال تحليل آراء المبحوثين ذكوراً كانوا أم إناثاً في الدور الذي لون تقوم به المدرسة لحماية الشباب من الوقوع في أنماط الجريمة المختلفة، وذلك من البيانات الموضحة

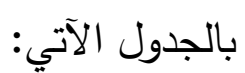

$$
\text { ج- دور المدرسة في الحد من الجريمة: }
$$
إذا كان الأسرة هي المؤسسة الأساسية التي تتولى تربية الطفل وتتشئته وبخاصة في مراحله الأولى على القيم الاجتماعية الايجابية، وإكسابه الأنماط السلوكية التي تتفق مع القيم الاجتماعية التي تتبناها، والتي تمثل مرجعية بالنسبة لها، فإن للمدرسة بوصفها مؤسسة تربوية دوراً أساسياً أيضاً في تعليم 


\begin{tabular}{|c|c|c|c|c|}
\hline \multirow[t]{2}{*}{ الترتيب } & \multirow{2}{*}{ الإجمال } & \multicolumn{2}{|c|}{ 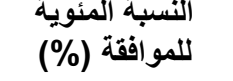 } & \multirow[t]{2}{*}{ 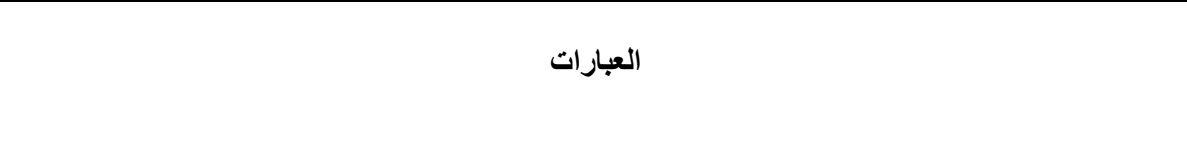 } \\
\hline & & إناث & ذكور & \\
\hline 1 & 99.4 & 99 & 100 & تو عية الطلاب بقو اعد السلوك و المو اظبة يبعدهم عن الجريمة \\
\hline 1 & 99.4 & 99 & 100 & وضكاب إدارة الددرسة خطة لمكافحة الجريمة و العنف وسط الطلاب تسهم فى تو عية الثباب و ابعادهم عن \\
\hline 5 & 75.21 & 97.9 & 91.1 & وضع خطة لإرشاد الطلبة عن المشكلات الطلابيـة المنوقعة تقلل من اشتر اكهم فى احداث العنف و الجريمة. \\
\hline 2 & 97 & 98.9 & 94.5 & تتفيذ حملات توعية لمكافحة السلوك السلبي للطلاب تساعد في الوقاية من الجريمة. \\
\hline 7 & 88.37 & 97.4 & 78.7 & إنشعار أولياء الأمور بمخالفـات أبنـائهم في المدرسة يحد من السلوك الاجر امي. \\
\hline 6 & 91.4 & 97.4 & 83.6 & إنر الك الطلبة في صنع القرارات المدرسية يقلل من حدوث الجريمة. \\
\hline 10 & 91.16 & 97.4 & 84.3 & الابتعاد عن أساليب العقاب البذني يقلل من ارتكاب الجريمة.. \\
\hline 7 & 93.38 & 96.4 & 89 & 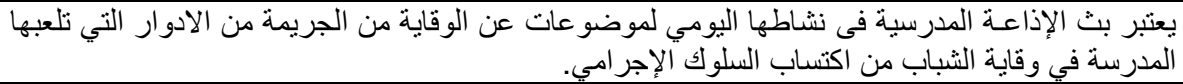 \\
\hline 9 & 89.7 & 96.9 & 80.1 & 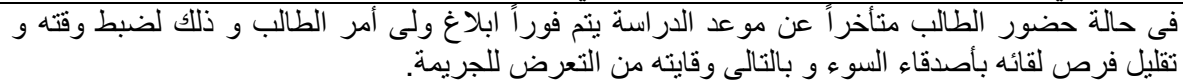 \\
\hline 5 & 93.49 & 97.4 & 88.3 & إعداد نشر ات لتوعية الطلاب بمخاطر السلوك الإنحر افي في المدرسة يقلل من وقوع الجريمة. \\
\hline 9 & 91.6 & 97.4 & 84.2 & إنشر اك الطلاب في الأندية الصيفية يقضي علي فرص ارتكاب الجريمة. \\
\hline 12 & 85.6 & 95.4 & 84.9 & الطلاب من الميل اللسلوك لأساليب العقاب و الجزاء الماء ذات الإيذاء النفسي كالتوبيخ و السخرية و غير ها يقى \\
\hline 3 & 85.3 & 97.4 & 90 & الذات والاخرين و وحفيز السعدوك عن الإيجريمة والتفوق الدراسي للطلاب يرفع من مكانتهم و يشعر هم بالأهمية و تقدير \\
\hline 9 & 94.3 & 96.9 & 91.1 & إرشاد وتو عية الطلاب المتأخرين در اسياً يسهم فى شعور هم بالقبول اجتماعياً و يقيهم من التعرض الجريمة. \\
\hline 7 & 91.7 & 96.4 & 80.6 & الجريمة. المدرسة لخطط ارشادية و مر اقبة سلوك من لايهم بوادر انحراف من الطلاب يقيهم من ارتكاب \\
\hline 12 & 87.6 & 96.4 & 76 & أنشتريمة. الطلبة في النشاط المدرسي و الجمعيات الطلابية حسب ميول و رغبات كل منهم يقلل من الميل نحو \\
\hline 3 & 87.6 & 97.9 & 84.4 & العمل على شغل وقت فراغ الطلاب في أمور هامة أثناء الدوام الرسمي يبعدهم عن الجريمة. \\
\hline 3 & 78.34 & 97.9 & 84.9 & من الجريمة. التعاون مع الأجزةة الأمنية المعنية إذا ما ظهرت سلوكيات خطيرة من قبل بعض الطلاب بقلل \\
\hline 4 & 92.3 & 97.9 & 84.9 & الجزيمة سياسات الإرشاد الديني في الددارس للطلبة حول مخاطر السلوك الاجر امي يمنع انخراط الطلاب فى \\
\hline 9 & 91.3 & 96.4 & 84.9 & المساعدة من قبل المدرسة في تعميق العلاقة بين الطالب و الأسرة يقلل من الجريمة. \\
\hline 8 & 93.5 & 95.9 & 90.4 & إنعقاد مجالس أولياء الأمور بشكل دوري لمناقشة أوضاع الطلبة يقلل من الجريمة. \\
\hline 14 & 83.99 & 95.3 & 89 & إبلاغ السلطات الأمنية عن السلوكيات الاجر امية لبعض الطلبة يبعد الطلاب عن الجريمة. \\
\hline 10 & 89.08 & 96.4 & 79.4 & تعميق العلاقة بين الطلبة والمعلمين في الددرسة يبعدهم عن الجريمة. \\
\hline 11 & 90.1 & 95.8 & 84.9 & إرشاد وتوجيه الطلبة الذين يعانون من مشاكل أسرية يقلل من الجريمة. \\
\hline 13 & 84.3 & 95.8 & 69.2 & إرشاد وتوجيه الطلبة الذين يعانون من مشاكل نفسية يقضي علي الجريمة. \\
\hline 7 & 79.9 & 97.4 & 78.1 & المساعدة في حل مشكلات الطلبة الذين يعانون من بعض المشاكل المدرسية يبعدهم عن الجريمة. \\
\hline 5 & 93.2 & $\begin{array}{c}97.4 \\
1\end{array}$ & 87.7 & الجريمة. الإككانات المادية والتجهيزات الضرورية في المدرسة من ملاعب وصالات ومكتبات وخلافه يقلل من \\
\hline & & & 4.2 & 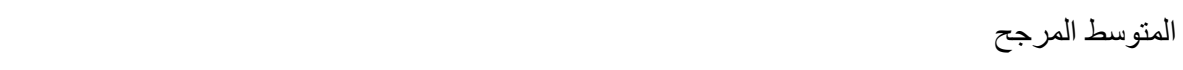 \\
\hline
\end{tabular}


الوقاية من الوقوع في الجريمة، وقد جاءت تلك الفروق لصالح فئة الإناث.

- ثم تأتي نسبة 94.3\% من مجموع أفراد العينة بالموافقة على أن إرشاد وتوعية الطلاب المتأخرين

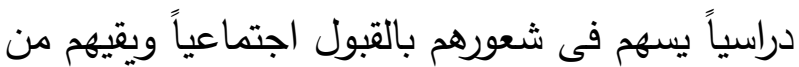
التعرض للجريمة، وقد جاءت نسب الاستجابات متقاربة بين الذكور والإناث، فقد بلغت بنسبة 96.9

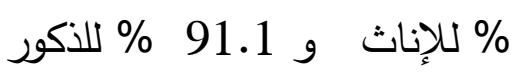
- يليها في الترتيب الاستجابات التي بلغت نسبتها

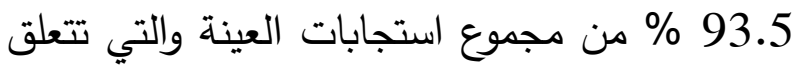
بالموافقة على أن انعقاد مجالس أولياء الأمور بشكل دوري لمناقشة أوضاع الطلبة يقلل من الجريمة، وبينما بلغت نسبة الاستجابات بالموافقة على العبارة \% \% \% من جانب الإناث، بلغت نسبة الاستجابات

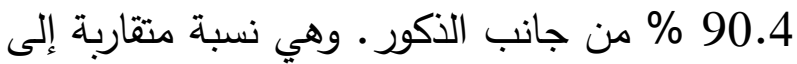
حد كبير ، مما يشير إلى إتفاق عينتي الدراسة بالرغم

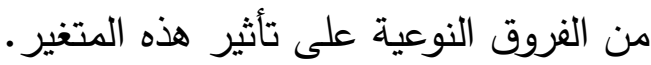
- أما فيما يتعلق بالموافقة على أن إعداد نشرات لتوعية الطلاب بمخاطر السلوك الانحرافي في المدرسة يقلل من وقوع الجريمة، فقد بلغت النسبة

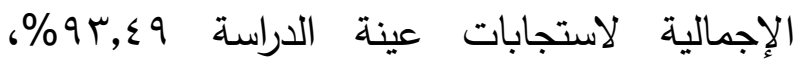
وبينما بلغت نسبة الاستجابات بالموافقة على العبارة 9V, ₹ \% من جانب الإناث، بلغت نسبة الاستجابات

على المتغير ذاته 88.3 \%بالنسبة للذكور . - وفيما يتصل بالموافقة على أن بث الإذاعة المدرسية فى نشاطها اليومي لموضوعات عن الوقاية
تكثف البيانات والتحليلات الاحصائية الموضحة في الجدول السابق عن مجموعة من النتائج نوضحها فيما يأتي: - تكثف البيانات أن أعلي نسبة هي 99.4 \%من مجموع أفراد العينة الذين قد أجابوا بالموافقة على أن أن الن توعية الطلاب بقواعد السلوك والمواظبة يُبعدهم عن الجريمة. وكانت نسبة الإناث اللاتي أجبن بالموافقة

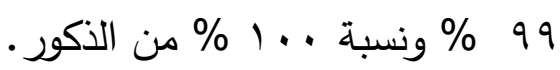

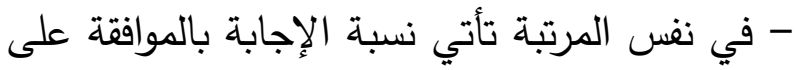

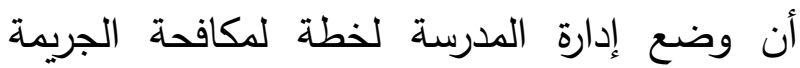
والعنف وسط الطلاب تسهم فى توعية الثباب وتنأى بهم عن ارتكاب الجريمة، وهي نسبة بلغت 99.4

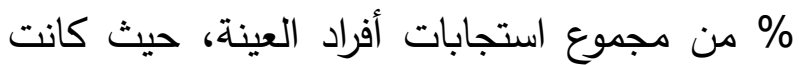
الإجابة بالموافقة على العبارة بنسبة 99 \% للإناث ونسبة . . 1 \% للذكور • - تليها في الترتيب أن 97.0 \% م من مجموع استجابات عينة الدراسة الذين أكدوا بموافقتهم على هن أن تتفيذ حملات توعية لمكافحة السلوك السلبي للطلاب تساعد في الوقاية من الجريمة. وبينما بلغت نسبة الاستجابات بالموافقة على العبارة 98.9 \% من جانب الإناث، لم تتجاوز نسبة استجابات الذكور

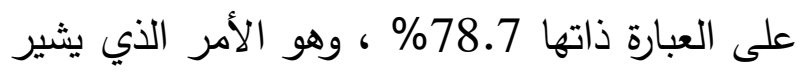
إلى تباين وجهات نظر الذكور والاناث فيما يتعلق بالمتغير الخاص بأن تتفذ المدرسة حملات توعية لونات

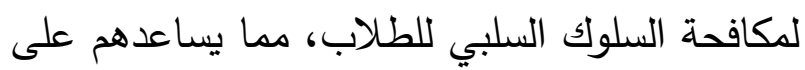


لايهم بوادر إنحراف من الطلاب يقيهم من ارتكاب الجريمة. وثمة فروق واختلافات بين وجهات نظر الإناث والذكور فيما يتعلق بدرجة الموافقة على هذا المتغير، فبينما بلغت نسبة الاستجابات بالموافقة على العبارة ـ, ج9 \% من قبل الإناث، لم تتجاوز النسبة 80.6 \% من جانب الذكور . - وتوضح البيانات أيضاً أن نسبة 91.6 \%من مجموع استجابات أفراد العينة قد أكدوا على الموافقة أفيات

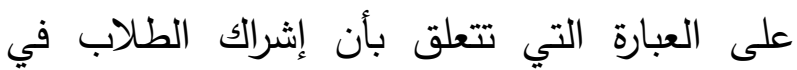
الأندية الصيفية يقضي على فرص ارتكاب الجريمة. وبينما بلغت نسبة الاستجابات بالموافقة على العبارة

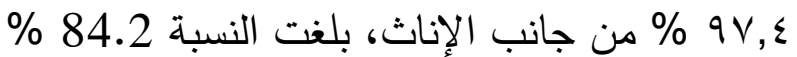

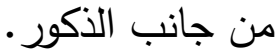
- أن نسبة 91.4 \% من مجموع أفراد العينة أجابوا بالموافقة على أن إثراك الطلبة في صنع القرارات المدرسية يقلل من حدوث الجريمة. وبينما بلغت نسبة

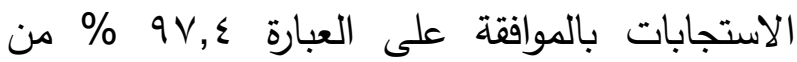
جانب الإناث، بلغت النسبة 83.6\% من جانب

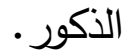

- تشير البيانات إلى أن النسبة الاجمالية لاستجابات عينتي الدراسة قد بلغت 91.3 \% فيما يتعلق بالموافقة على أن المساعدة من قبل المدرسة في لاعل تعميق العلاقة بين الطالب والأسرة يقلل من الجريمة. وثمة إختلافات بين براء الذكور والإناث في درجة

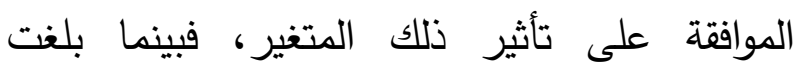
الاستجابات بالموافقة على العبارة ع, ج9 \%من
من الجريمة يعتبر من الأدوار التي تلعبها المدرسة في وقاية الثباب من اكتساب السلوك الإجرامي، فإن لإن لإنان

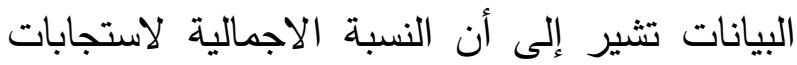
عينة الدراسة قد بلغت ^r,rو\% من مجموع الاستجابات. وثمة بعض الفروق والاختلافات بين نسبة استجابات الموافقة على المتغير، حيث بلغت النسبة 96.4 \% من جانب الإناث، ونسبة 89 \% لنهية

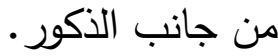
- كما تشير البيانات أيضاً إلى أن 93.2 \% من مجموع أفراد العينة أجابوا بالموافقة على أن توافر الإمكانات المادية والتجهيزات الضرورية في المدرسة التهات من ملاعب وصالات ومكتبات وخلافه يقلل من الجريمة، وفي حين بلغت نسبة الإستجابات بالموافقة على العبارة 97.41 \% من جانب الإناث، بلغت نسبة الاستجابات 87.7 \% من جانب الذكور . - أوضحت البيانات أيضاً أن 92.3 \% من من هموع استجابات أفراد العينة التي تئكد على متغير الموافقة على أن تبني سياسات الإرشاد الديني في المدارس للطلبة حول مخاطر السلوك الإجرامي يمنع انخراط الطلاب فى الجريمة. وبينما جاءت الاستجابات بالموافقة على العبارة بنسبة 97.9 \% من جانب الإناث، بلغت نسبة الاستجابات بالموافقة على العبارة 84.9 \% من جانب الذكور . - كما تشير البيانات كذلك إلى أن نسبة 91.7 \%

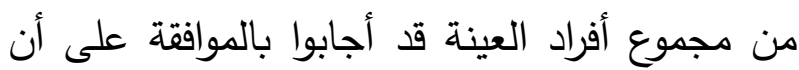

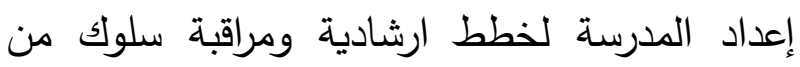


جاءت الفروق لصالح الإناث، وهو ما يعني أن الإناث أكثر وعياً بأهية دور أولياء أمور الطلاب الناب

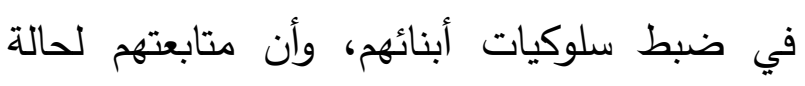
الأبناء في الددرسة يُعد أمراً مهماً، حيث يمثل ذلكان

الاهتمام من جانب كل من الددرسة والأسرة حصناً - أوضحت البيانات الميدانية أن النسبة الاجمالية لاستجابات المبحوثين بلغت 89.08 \% من مجموع اليان أفراد العينة قد أكدوا بالموافقة على أن تعيق العلاقة

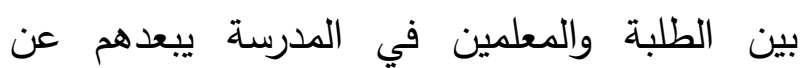
الجريمة، وبينما بلغت الاستجابات بالموافقة على فئل العبارة نسبة 96.4 \% من جانب الإناث، لم تزد

$$
\text { النسبة 79.4\% من جانب الذكور. }
$$

- كما أوضحت النسبة الاجمالية للإستجابات والتي بلغت 88.37 \% من مجموع إستجابات العينة الذين أجابوا بالموافقة على أن إثعار أولياء الأمور

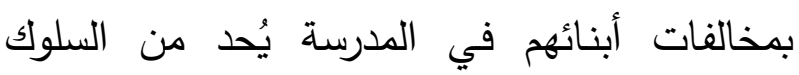
الإجرامي. فبينما جاءت الإجابة بالموافقة على العبارة نسبة 97.4 \% من جانب الإناث، ونسبة 78.7 \% من جانب الذكور .

- كما أوضحت البيانات أيضاً أن النسبة الاجمالية للإِستجابات بلغت 87.6 \% من مجموع إستجابات العينة الذين أجابوا بالموافقة على أن إشتراك الطلبة

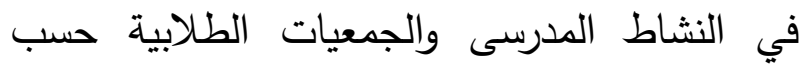
ميول ورغبات كل منهم يقلل من الميل نحو الجريمة. وبينما بلغت الاستجابات بالموافقة على العبارة نسبة
جانب الإناث، بلغت النسبة بالموافقة على المتغير

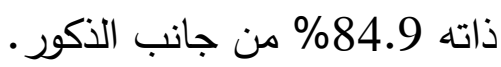
- كما كثفت التحليلات أيضاً والتي تعبر عن استجابات عينة الدراسة أن النسبة الاجمالية للاستجابات التي أكد المبحوثين من خلالها على الإلى

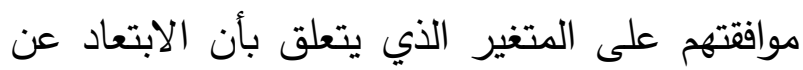

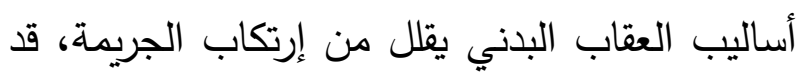

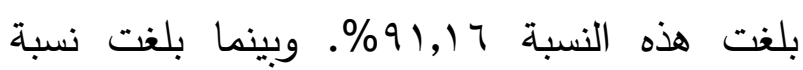

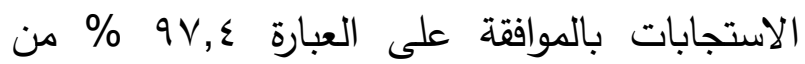
جانب الإناث، تثير البيانات إلى أن نسبة الاستجابات على المتغير ذاته قد بلغت 84.3\% من الانيات

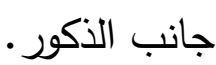

- أوضحت التحليلات الاحصائية التي تعكس التحس استجابات المبحوثين عينتي الدراسة أن النسبة الإنة الاجمالية للإستجابات والتي بلغت 89.7 \% من السابن مجموع أفراد العينة قد أكدوا بالموافقة على أنه فى الإن 89.7 حالة حضور الطالب متأخراً عن موعد الدراسة يتم فوراً إبلاغ ولى أمر الطالب، وذلك لضبط وقته وتقليل فرص لقائه بأصدقاء السوء، وبالتالي وقايته من التعرض للجريمة. وتثير البيانات كذلك إلى أن ثمة فروق التئق واختلافات بين آراء الإناث والذكور في درجة الثات الموافقة على المتغير ذاته، فبينما بلغت نسبة الموافقة على العبارة 96.9 \% من جانب الإناث، لم تتجاوز النسبة 80.1 \% من جانب الذكور • وتحول دون وقوع الطلاب في الجريمة والسلوك الانحرافي. وقد 
بلغت نسبة الاستجابات بالموافقة على العبارة 97.4 \% من جانب الإناث، بلغت النسبة 90.0 \% من

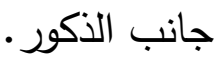
- كما أوضحت البيانات أن نسبة 84.3 \% من مجموع أفراد العينة أجابوا بالموافقة على أن إرشاد وتوجيه الطلبة الذين يعانون من مشاكل نفسية يقضي علي الجريمة، كما تشير البيانات التفصيلية إلى أنه بينما بلغت نسبة إستجابات الإناث بالموافقة على العبارة 95.8 \% بلغت نسبة استجابات الذكور على ذات المتغير 69.2 \% من مجموع

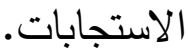

- وفي حين بلغت النسبة الاجمالية للاستجابات 83.99 \% فيما يتعلق بالموافقة على أن إبلاغ السلطات الأمنية عن السلوكيات الإجرامية لبعض الطلبة يبعد الطلاب عن الجريمة، فثمة فروق واختلافات بين عينتي الدراسة فيما يتعلق بالموافقة على تأثير المتغير ذاته، يث بلغت نسبة الاستجابات على العبارة 95.3 \% من جانب الإناث، بلغت نسبة الاستجابات 19 \% من جانب

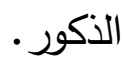

وفيما يتعلق بباقي المتغيرات الموضحة بالجدول والمتمثلة في الموافقة على أن المساعدة في حل مشكلات الطلبة الذين يعانون من بعض المشاكل المدرسية يبعدهم عن الجريمة، والموافقة على أن التنسيق والتعاون مع الأجهزة الأمنية المعنية إذا ما ظهرت سلوكيات خطيرة من قبل بعض الطلاب يقلل
96.4 \% من جانب الإناث ونسبة 76.0 \%من جانب الذكور - كما أوضحت البيانات أيضاً أن النسبة الاجمالية قد بلغت 87.6 \% من مجموع أفراد العينة الذين أجابوا بالموافقة على أن العمل على شغل وقت فراغ التران

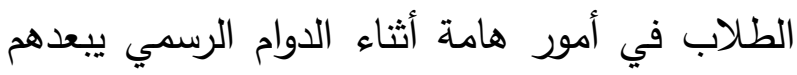
عن الجريمة. فبينما بلغت استجابات الإناث بالموافقة على العبارة نسبة 97.9\%، بلغت النسبة 84.4 \% من جانب الذكور . - ومن جانب آخر بلغت النسبة الاجمالية للاستجابات 85.6 \% من مجموع أفراد العينة قد أجابوا بالموافقة على أن عدم ممارسة المدرسة

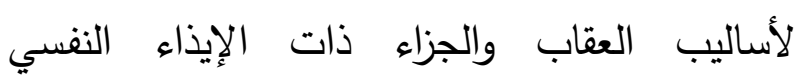
كالتوبيخ والسخرية وغيرها يقى الطلاب من الميل اللسلوك الإجرامي. كما تشير البيانات أيضاً إلى أن

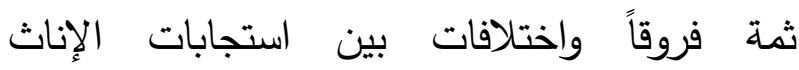
واستجابات الذكور فيما يتعلق بدرجة الموافقة على الى الثات تأثير المتغير ذاته، فبينما بلغت نسبة الاستجابات على العبارة 95.4 \% من جانب الإناث، بلغت نسبة الاستجابات على المتغير ذاته 84.9 \%من جانب الذكور - وتؤكد البيانات كنلك على أن نسبة 85.3 \% من مجموع أفراد العينة قد أجابوا بالموافقة على أنس أن 85.3 تثجيع وتحفيز السلوك الإيجابي والتفوق الدراسي

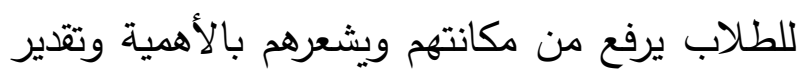
الذات وتقدير الاخرين ويبعدهم عن الجريمة. وبينما 
التي تعكس استجابات عينتي الدراسة تثير إلى مجموعة من النتائج نذكرها فيما يأتي:

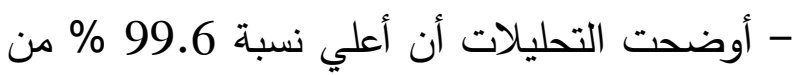
مجموع أفراد العينة قد أجابوا بالموافقة على أن دمج اعلية

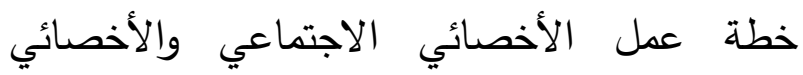
النفسي بخطة المدرسة يوحد الجهود ويحقق هدف الاجسي وقاية الطلاب من المشاكل الاجتماعية والنفسية التي وني تقود إلى إرتكاب الجريمة. وبينما جاءت الاستجابات

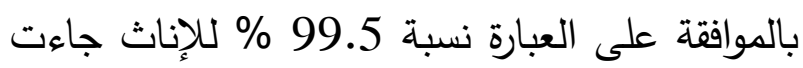

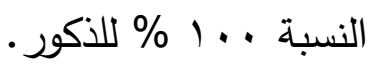

- وفي المرتبة الثانية بلغت النسبة الإجمالية 97.34 \%من مجموع استجابات العينة الذين أكدوا بالموافقة على أن إعداد الأخصائي الاجتماعي لملفات وسجلات الطلاب ومتابعة ورصد ومراقبة

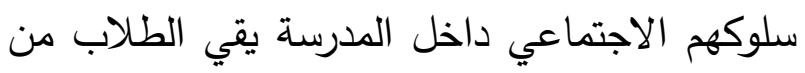
ارتكاب الجريمة. وبينما جاءت الإجابة بالموافقة على لعى لفي هذه العبارة بنسبة بلغت 99.5 \% من جانب جانب الإناث، بلغت نسبة الاستجابات 94.5 \%من جانب

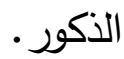
- أوضحت البيانات أيضاً أن نسبة 93.2 \% من مجموع أفراد العينة قد أجابوا بالموافقة على أن تقديم

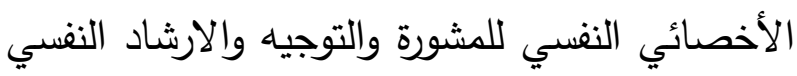
الخاص بالطلاب للمدرسين وأولياء الأمور يرفع من الأني

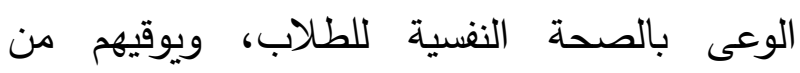
الإنحراف والجريمة. فبينما بلغت نسبة الاستجابات
من الجريمة. والموافقة على أن وضع خطة لإرشاد

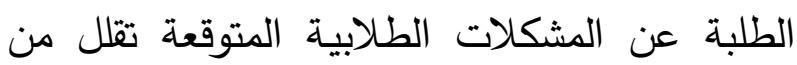
اشتراكهم فى احداث العنف والجريمة. فقد جاءت النسب الاجمالية لاستجابات أفراد العينة على تلك الك المتغيرات متباينة، كما أنها تعكس في الوقت ذاته لاته

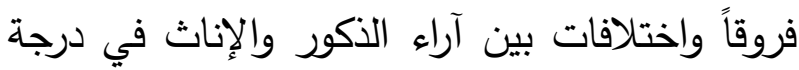
ومدى تأثير أي من تلك المتغيرات في إرتكاب الطلاب للجريمة والسلوكيات الإنحرافية، والبيانات المبينة بالجدول تكثف عن ذلك بشكل واضح. د- أهمية دور الأخصائي الاجتماعي والأخصائي النفسي في الوقاية من الجريمة: يعتبر دور الأخصائي الاجتماعي والأخصائي

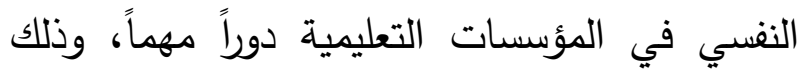
لدراسة وفهم وتثخيص المشكلات المتتوعة التي قد يعاني منها الطلاب في مختلف المراحل الدراسية، ومن ثم، فإن هذا الدور قد يمتد في بعض الحالات لدراسة أسر الطلاب الذين يعانون من مشكلات سواء

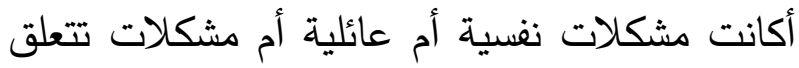
بالتحصيل الدراسي.... وغيرها من المشكلات الأخرى. لذلك فإن تحليل وجهات نظر عينتي الدراسة وآرائهم في الدور الذي يقوم به كل من الأخصائي الاجتماعي والأخصائي النفسي في وقاية الطلاب من الوقوع في الجريمة يمثل أحد المحاور المهمة في الدراسة، وذلك على إعتبار أن كل منهما

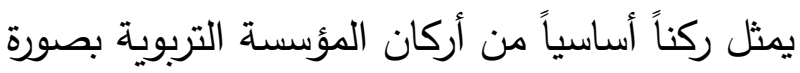
عامة. وفي هذا السياق، فإن تحليل البيانات الميدانية 
- ومن ناحية أخرى، تكشف البيانات أن نسبة 90.9 \% من مجموع استجابات أفراد العينة قد أجابوا

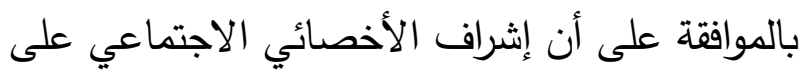

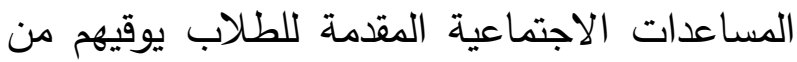
الحاجة المادية، ويحميهم من الوقوع في الجريمة. فبينما بلغت نسبة الاستجابات بالموافقة على هذه العبارة 91,0 \% من جانب الإناث، جاءت نسبة الاستجابات 90.4 \% من جانب الذكور • - وأخيراً بلغت أدني نسبة الاستجابات 90.8 \% من مجموع استجابات أفراد العينة الذين أجابوا لانجات التهات بالموافقة على أن تنظيم وتتفيذ الأخصائي النفسي لجلسات الإرشاد النفسي الفردي والجماعي للطلاب تسهم فى وقايتهم من الجريمة والسلوك الإجرامي. وأنه بينما بلغت نسبة الاستجابات بالموافقة على هذه هن

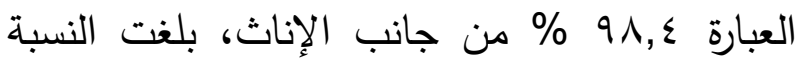
80.8 \% من جانب الذكور. وجاءت في نفس

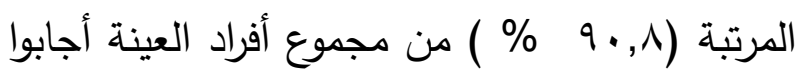

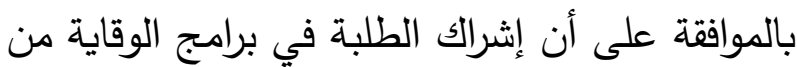

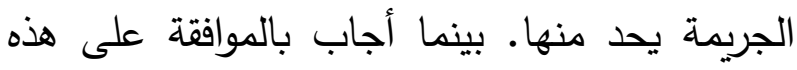

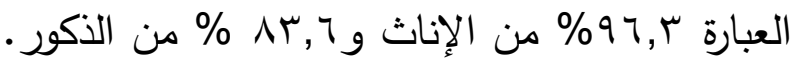
وقد بلغ المتوسط المرجح r,ک وهو معدل عالي.

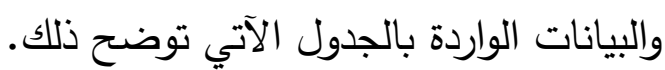

بالموافقة على هذه العبارة ع,، 9 \% من جانب الإناث، بلغت النسبة 89.00 \%من جانب الذكور . - كما كثفت البيانات كذلك عن أن النسبة الاجمالية لاستجابات العينة والتي بلغت 92.9 \% من مجموع الاستجابات قد أكدوا على موافقتهم على أن دراسة

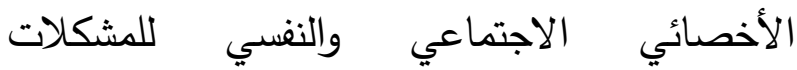
الاجتماعية والنفسية والسلوكية للطلاب مثل حالات التيلي بطيء التعلم والنشاط الزائد والهروب من المدرسة يقلل من نسبة الفاقد التربوي ويقي الطلاب من من الجريمة. وبينما بلغت نسبة الاستجابات بالموافقة

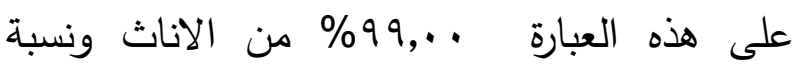

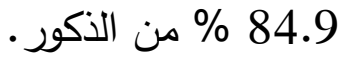

- أما بالنسبة للمتغير الخور، بأن إثراف

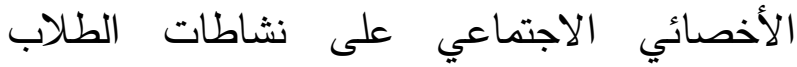
وربطها بالمجتمع يسهم في إكتساب الطلاب للعادات والتقاليد الاجتماعية الايجابية، فإن النسبة الاجمالية لاستجابات عينة الدراسة الذين وافقوا على تأثير هذا المتغير قد بلغت r, צ9\% من مجموع الاستجابات.

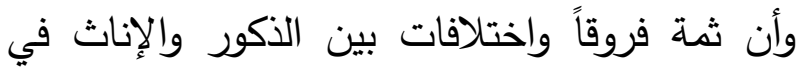
وجهات نظرهم فيما يتعلق بتأثير هذا المتغير ، فبينما جاءت الإجابة بالموافقة على هذه العبارة بنسبة 98.5 \% من جانب عينة الإناث بلغت النسبة 84.3 \% من جانب الذكور 


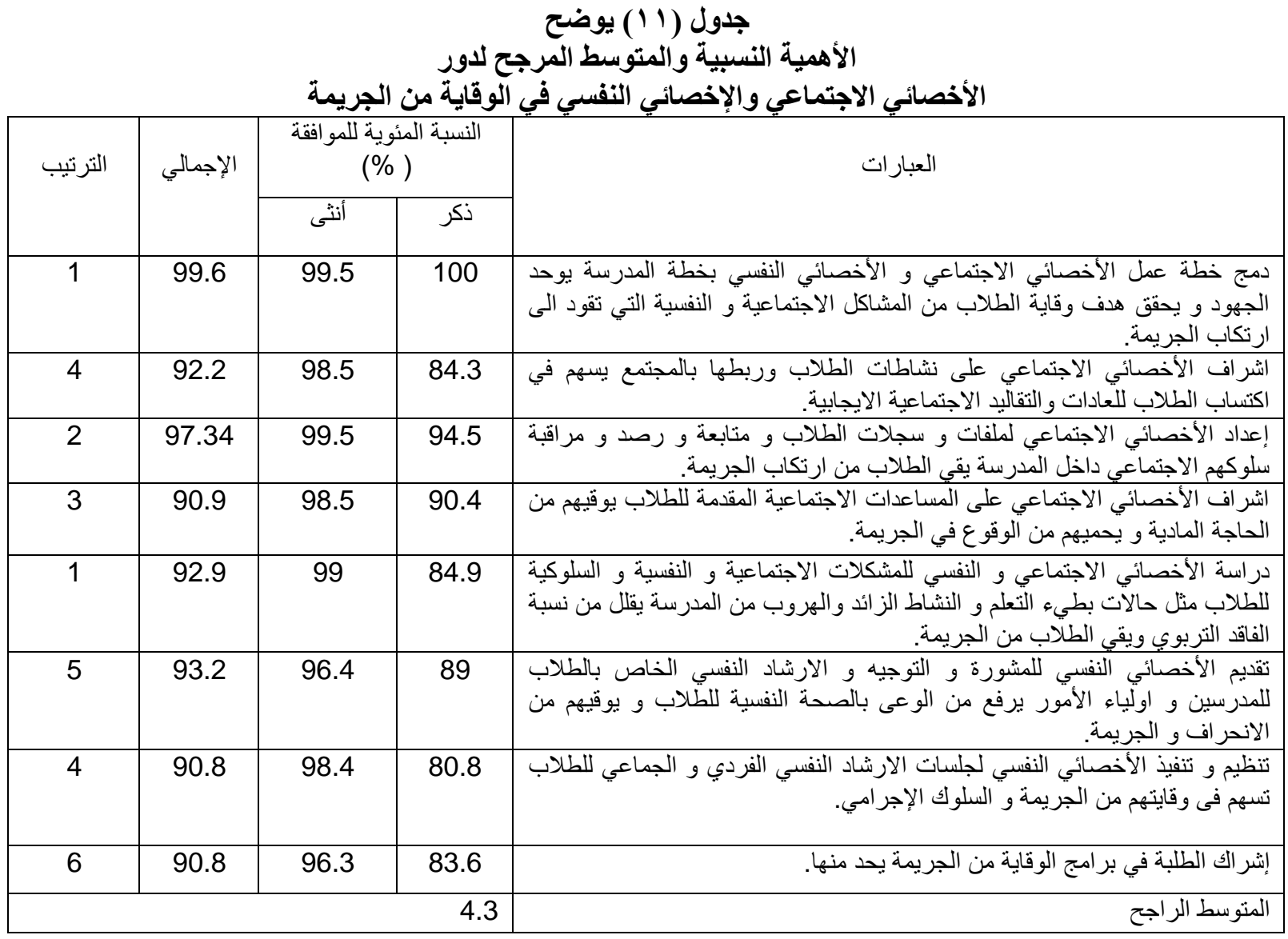

الجريمة والسلوك الإنحرافي بأشكاله المختلفة، فلا شك في أن ثمة مجموعة من المغوقات التي قد تحول دون قيام تلك المؤسستين بأدوارهن كما يجب أن تكون. ويمكننا الكثف عن تلك المعوقات من لن خلال البيانات الموضحة بالجدول الآتي:
هـ - المعوقات التي تحول دون تفعيل دور كل من الأسرة والمدرسة في الوقاية من الجريمة: إذا كانت التحليلات السابقة قد أكدت على أن ثمة أدواراً مهمة ينبغي أن تقوم بها كل من الأسرة كمؤسسة اجتماعية والمدرسة كمؤسسة تربوية، تلك الأدوار التي من شأنها وقاية الطلاب من الوقوع في 
جدول (r I ) يوضح )

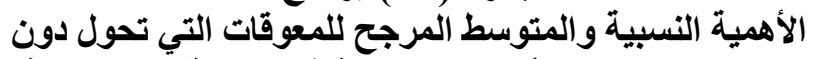

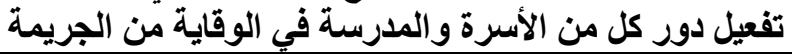

\begin{tabular}{|c|c|c|c|c|}
\hline \multirow[b]{2}{*}{ الترتيب } & \multirow[b]{2}{*}{ الإجمالي } & \multicolumn{2}{|c|}{$\begin{array}{c}\text { النسبة المئوية للمر افقة } \\
\text { (\%) }\end{array}$} & \multirow[b]{2}{*}{ 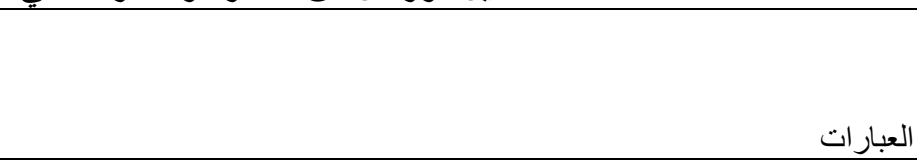 } \\
\hline & & أنثى & ذكر & \\
\hline 1 & 96.1 & 97.9 & 100 & عمليات وجود ضنشئة الاجنماعية. للبرامج التي تبث عبر القنوات الفضائية يحد من تفعيل دور \\
\hline 2 & 96.4 & 97.9 & 94.5 & التربية المتردية تحول دون تفعيل دور عمليات التنشئة الاجتماعية. \\
\hline 3 & 94 & 96.9 & 90 & الاجنماعية. الثباب على الحلال و الحرام يحد من تفعيل دور عمليات التنشئة \\
\hline 4 & 90.5 & 96.9 & 82.2 & التفكك الأسرب يحد من تفعيل دور عمليات التنشئُة الاجتماعية. \\
\hline \multicolumn{4}{|c|}{4.3} & المتوسط الر اجح \\
\hline
\end{tabular}

الإناث، بلغت نسبة الاستجابات 94.5 \% من

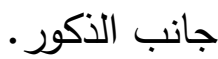

- وفي المرتبة الثالثة، بلغت النسبة الاجمالية

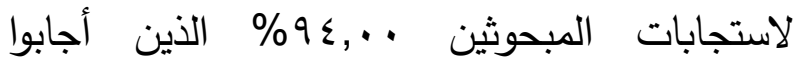
بالموافقة على أن عدم وجود ضوابط للبرامج التي تبث عبر القنوات الفضائية يحد من تفعيل دور عمليات التتشئة الاجتماعية. وتشير البيانات التفيلية الموضحة بالجدول إلى تقارب نسبة استجابات كل من الذكور والإناث حول تأثير هذا المتغير، فبينما بلغت نسبة إستجابات الإناث بالموافقة على العبارة 96.9 \%، بلغت نسبة الاستجابات .9 \% من جانب الذكور. - وجاء المتغير الخاص بالموافقة على أن التنكك الأسري يحد من تفعيل دور عمليات التتنئة الاجتماعية، والذي بلغتالنسبة الاجمالية لاستجابات

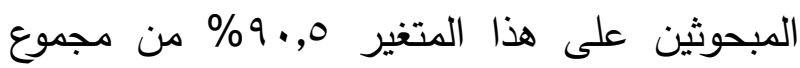

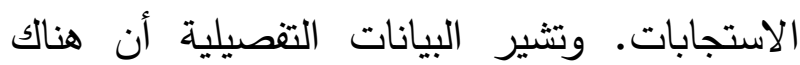

تكثف البيانات الموضحة بالجدول السابق والتي تتعلق بالأهمية النسبية والمتوسط المرجح للمعوقات التي تحول دون تفعيل دور كل من الأسرة والمدرسة في الوقاية من الجريمة عن مجموعة من المعوقات جاء ترتيبها وفقاً لدرجة أهميتها ومستوى خطورتها

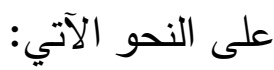
- إحتل متغير عدم وجود ضوابط للبرامج التي تبث عبر القنوات الفضائية يحد من تفعيل دور عمليات

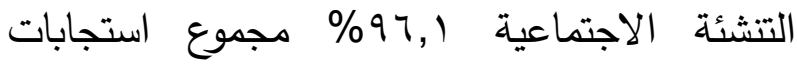

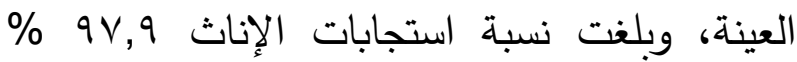
بينما بلغت نسبة استجابات الذكور تمثل .. 11\%. - بينما جاء في المرتبة الثانية متغير أن التربية المتردية تحول دون تفعيل دور عمليات التنشئة الاجتماعية، وقد بلغت النسبة الاجمالية لاستجابات المبحوثين بالموافقة على هذا المتغير \&,ب99\% من مجموع الاستجابات. وبينما بلغت نسبة الإجابة بالموافقة على هذه العبارة 9V,9 \% من جانب 
للمقولة الوظيفية " الخلل الوظيفي") يؤثر بالتالي

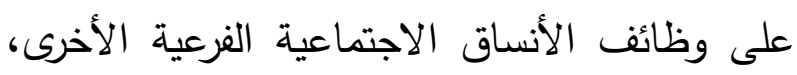

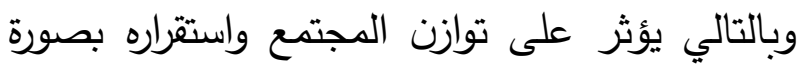
عامة.

2- دور الأخصائي الاجتماعي والأخصائي النفسي ودمج خطة عمل كليهما في الخطة المدرسية ويوحد الاجئ الجهود لتحقيق أهداف حماية الطلاب من المشاكل الاجتماعية والنفسية التي تؤدي إلى ارتكاب الجريمة

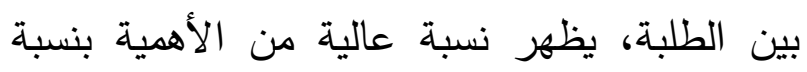

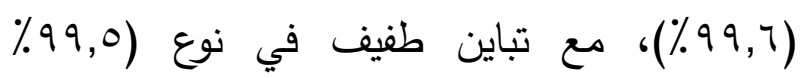
للذكور - . . ( ٪ للإناث). إن تتظيم وتنفيذ جلسات

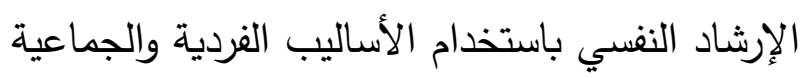
التي تساهم في الحماية من الجريمة والسلوك

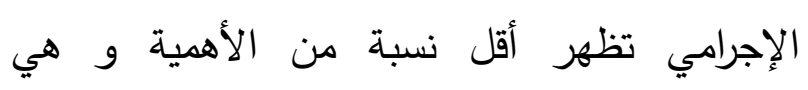

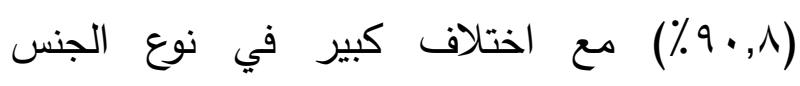

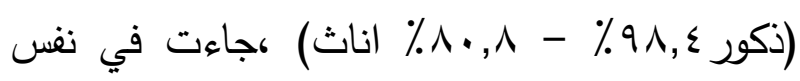

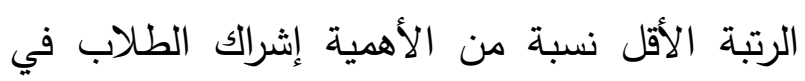

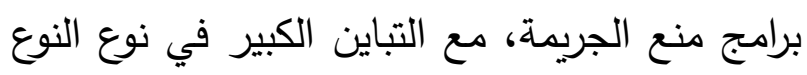

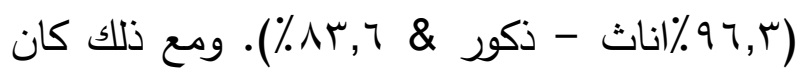
المتوسط المرجح ب, ـ مرتفع. 3- أهية دور التنشئة الاجتماعية عن طريق ترفئ توفير الطرق والطرق لحل المشاكل التي يواجهها الثباب هو أعلى نسبة مئوية (•r, (97\%)، من أي قياسات

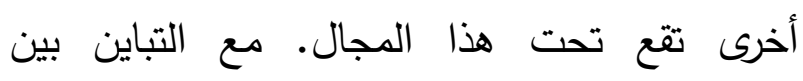

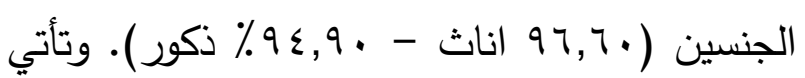
أهمية نقل التراث الثقافي والاجتماعي من جيل إلى
اختلاف بين نسبة استجابات الإناث ونسبة استجابات الذكور حول مدى ودرجة أهمية وتأثير هذا لئ المتغير ، حيث بلغت نسبة الموافقة على هذه العبارة

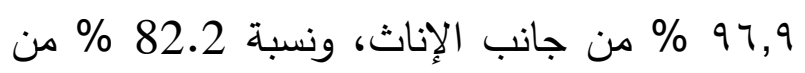

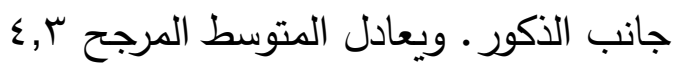
عاشراً: نتائج الدراسة: توصلت الدراسة إلى مجموعة من النتائج نذكر منها: 1-على المستوى النظري تمثل البنائية الوظيفية مدخلاً نظرياً مناسباً لفهم وتحليل دور المؤسسات

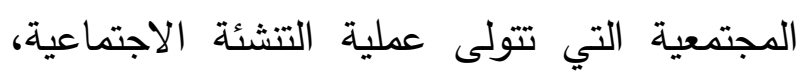
وبخاصة مؤسستي الأسرة والمدرسة، وذلك بوصفئهما أكثر المؤسسات ارتباطاً بالأبناء وبخاصة في مولئه مراحل العمر الأولى (الطفولة المبكرة ومرحلة المراهقة)، وهي المراحل التي يكتسب من خلالهما كل ما يتعلق بالعادات والتقاليد والتيم الاجتماعية وأنماط السلوك، والتي تسهم بدرجة أساسية في بناء شخصيته الاجتماعية. وهاتين المؤسستين تمثلان أنساقاً فرعية داخل النسق المجتمعي الأكبر (وفقاً للمنقولات الوظيفية)، وتؤدي كل مؤسسة منهن وظائف محددة

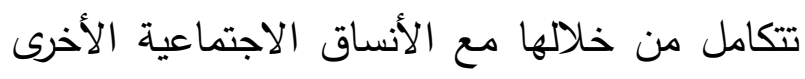

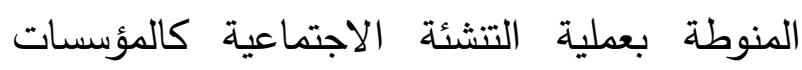
الإعلامية والمؤسسات الدينية والتثثيفية.... وغيرها

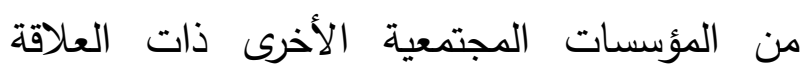
بعملية التشئئة الاجتماعية. ومن ثم، فإن تراجع دور ووظيفة هاتين المؤسستين في عملية التنشئة الاجتماعية للأبناء يترتب عليه خلاً وظيفياً (وفقاً 
مما يفسر أن وضع خطة لتوجيه الطلاب حول

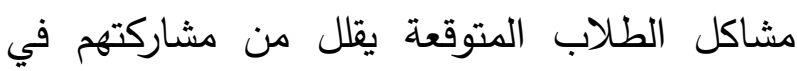

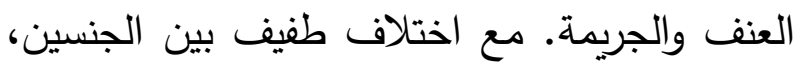
وبلغ المتوسط المرجح لدور المدرسة في مكافحة

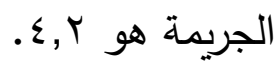

6- دور استقرار الأسرة للحد من مشاركة الشباب في

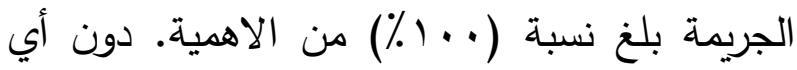
تباين في نوع الجنس. وانخفاض القياس هو

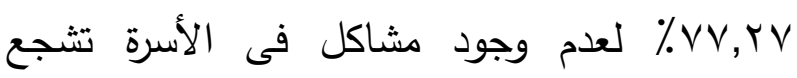
الشباب على عدم الخلط مع اصدقاء السوء. والمتوسط المرجح لدور الأسرة في منع الجريمة هو

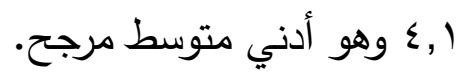
التوصيات

ثمة مجموعة من التوصيات والمقترحات التي يمكن

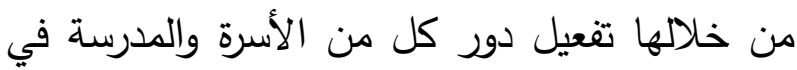
الوقاية من الجريمة نجملها فيما يأتي:

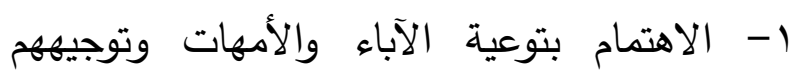

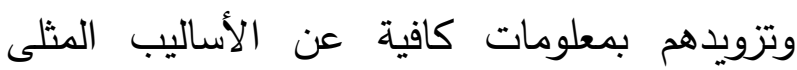
لتربية الأبناء في جميع المراحل العمرية. r- العمل على تعميق دور الأسرة من خلال التركيز على دورها في عملية التنشئة الاجتماعية، وذلك من التره خلال التتسيق والتعاون مع المؤسسات المجتمعية الأخرى، بهدف بناء جيل من الأبناء قادر على ليع

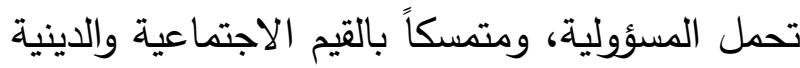
التي تسهم في الحد من الجريمة وأنماط الانحراف
جيل والالتزام بالتكامل مع مؤسسات التتشئة الاجتماعية الأخرى عند أدنى مستوى من الأهمية

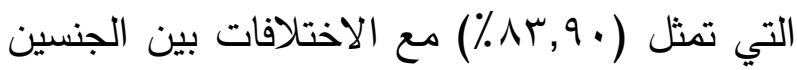

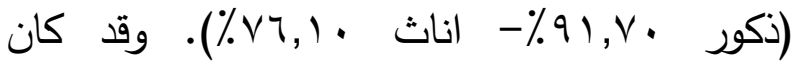
المتوسط المرجح مرتقع ب, ــ. ع- العقبات التى تحول دون فاعلية دور الأسرة والمدرسة في منع الجريمة سببها ضعف التعليم الذى النى يعيق تفعيل دور عمليات التتشئة الاجتماعية وقد

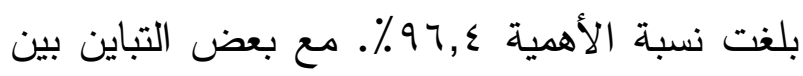

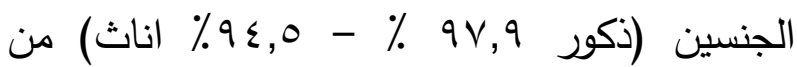
الذكور. أدنى نسبة من الأهمية هي ( (ه, •9\%) لقياس تنكك الأسرة يقلل من تفعيل دور عمليات

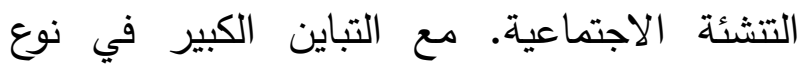

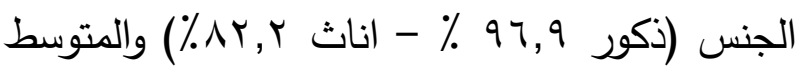
المرجح مرتفع ب, ع. 5- المجال الثالث للدراسة يوضح دور المدرسة في الحد من السلوك الإجرامي. وقد تم التأكد من ذلك دلك باثنين من نتائج القياس المتساوية لهذا المجال من حيث النسبة المئوية للأهمية ع, 99٪ بتثقيف الطلبة حول قواعد السلوك والمواظبة على الحضور وأهمية دور خطة الإدارة المدرسية في دمج القياسات لمكافحة الجريمة والعنف بين الطلاب للمساهمة في

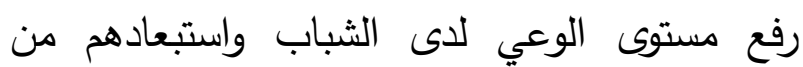
ارتكاب الجريمة وهو ما يمثل مع تباين طفيف في

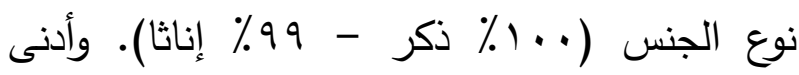

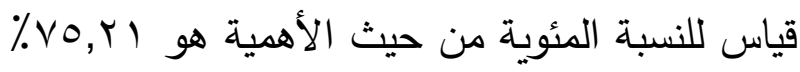


الخشاب، أحمد (917) الضبط الاجتماعي: أسسه النظرية وتطبيقاته العملية، مكتبة القاهرة الحديثة،

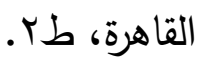

القصيرى، إنعام (1990) التنشئة الاجتماعية في

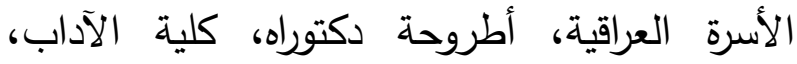

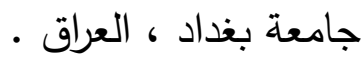
الخشاب، سامية (9AVV) النظرية الاجتماعية ودراسة الأسرة، دار المعارف، القاهرة .

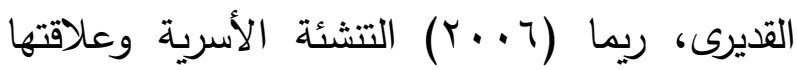
بانحراف الطلاب: دراسة حالة لمحافظة أبين، رسالة ماجستير غير منشورة، جامعة عدن، الجمهورية اليمنية. - مانير الساعاتى، سامية (ب1911) الجريمة والمجتمع، دار النهضة العربية، بيروت.

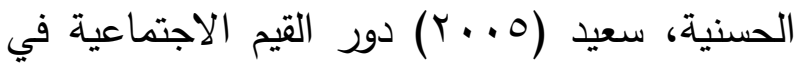
الوقاية من الجريمة. دراسة مسحية وصفيةعلى طلبة جامعة الإمام محمد بن سعود، ونزلاء إصلاحية،

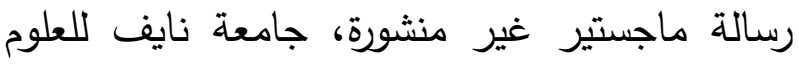
الأمنية، الرياض، المملكة العربية السعودية.

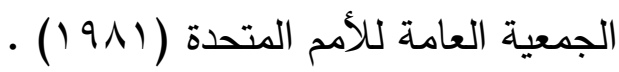

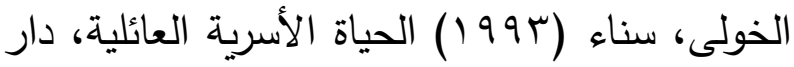

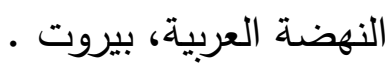
الخطيب، شحاته وأخرون (غير مبين سنة النشر)، أصول التربية الإسلامية، ص • • 17.

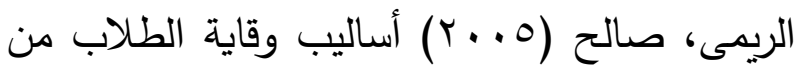
الانحراف كما يراها التربويين في المدارس المتوسطة الحكومية، رسالة ماجستير غير منشورة، جامعة نايف للعلوم الأمنية، الرياض، المثلكة العيلة العربية
المختلفة، وهو الأمر الذي يسهم في الحفاظ على

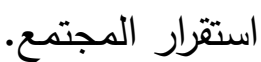
r- ضرورة تزايد الاهتمام بدور المدرسة في تتشئة الأطفال والثباب وفق طبيعة المتغيرات الاجتماعية والاقتصادية والثقافية المعاصرة، وتلبية احتياجاتهح وتتمية قدراتهم المعرفية وتوعيته بالمخاطر والتأثرات السلبية للجرية على كل من الفرد والأسرة والمجتمع بصورة عامة. ع- الاهتما بفئات الثباب العاطلين عن العمل، والعمل على توفير فرص عمل لهم تتناسب مع لهاب قدراتهم، ومن ثم تحويل هذه الطاقات والقوى البشرية من مستهلكة وعالة على المجتمع إلى طاقات منتجة تسهم في تحقيق التتمية المستدامة لمجتمعاتهم. 0- ضرورة أن يكون لوسائل الاعلام المختلفة التقليدية والرقمية دور فاعل ومؤثر في وقاية الثباب من الوقوع في دائرة الجريمة والانحراف، وذلك من خلال تقديم برامج وأعمال فنية تبين الآثار السلبية المترتبة على الجريمة والسلوك الانحرافي على الفرد

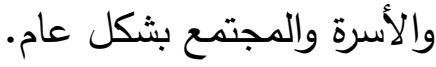
צ- توفير المناهج والمقررات الدراسية التي تؤكد على القيم الاجتماعية الإيجابية، والتي من شأنها تعميق شعور الشباب بالانتماء والولاء للمجتمع، ومن الإنياء ثم تحول بينهم وبين الوقوع في الجريمة والانحراف بأنماطه المختلفة.

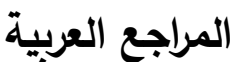

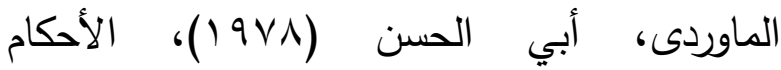
السلطانية، دار الكتب العلمية، بيروت، لبنان • 
دوركايم، إيميل ( ع (19V) قواعد المنهج في علم

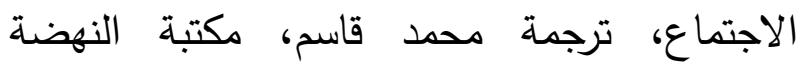
المصرية، القاهرة.

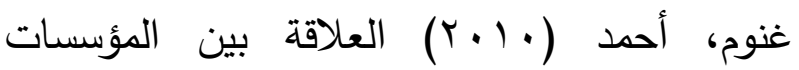

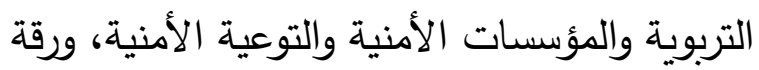

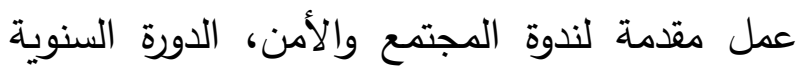

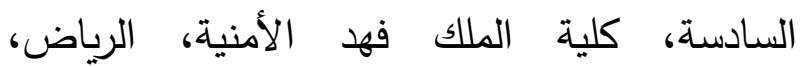

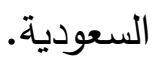

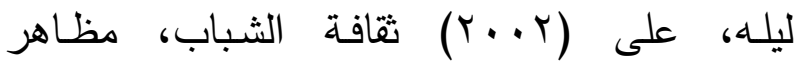
الانهيار ونشـأة الثقافات الفرعية، في أحمد أبو زيد

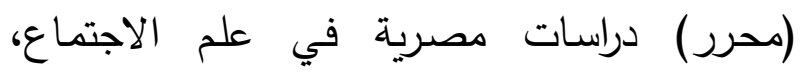
مطبوعات مركز البحوث والدراسات الاجتماعية،

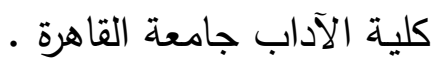

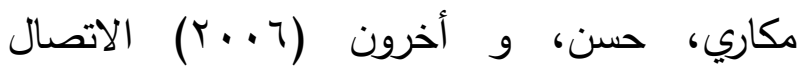
ونظرياته المعاصرة، الدار المصرية اللبنانية، القاهرة.

\section{المراجع الأجنبية}

Dekovic, M., Janssens, J. M., and van As, N. M. (2003). Family predictors of antisocial behavior in adolescence. Family Process, 42, 223-235.

Hale, Chris, and Hayward, Keith, and wincop, Emma. (2005). Criminology, by oxford university press Inc, New YOURK.

Lipsey, M.W., and Derzon, J.H. (1998). Predictors of violence or serious delinquency in adolescence and early adulthood. In R. Loeber and D.P. Farrington, (eds). Serious and Violent Juvenile Offenders: Risk Factors and Successful Interventions. (pp 86-105). Thousand Oaks, CA: Sage Publications, Inc. )

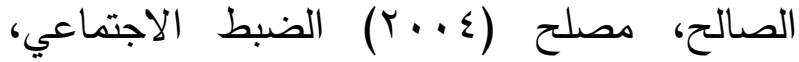

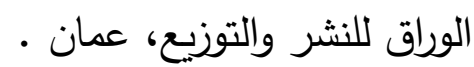
العبيدى ، محمد (·99 19) دور الأسرة في الوقاية من •

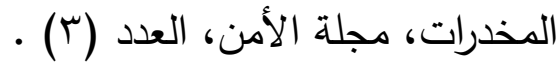

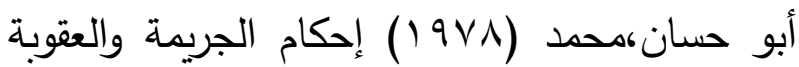
في الشريعة الإسلامية، مكتبة المنار، الزرقاء.

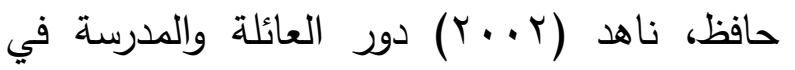

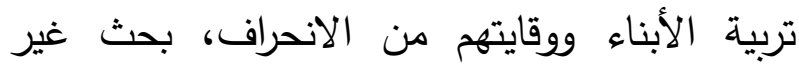
منشور ، كلية الآداب، جامعة بغداد، بغداد .

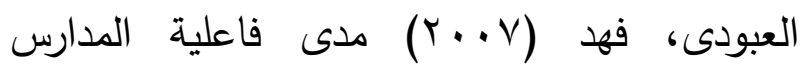

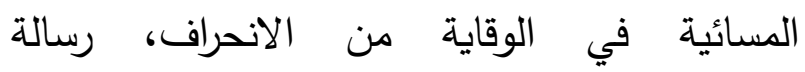
ماجستيرغير منشورة، جامعة نايف للعلوم العربية.

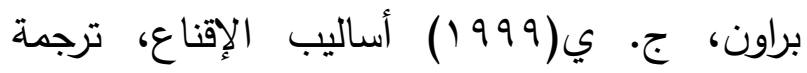
الخياط ، عبد اللطيف، دار الهدى، السعودية.

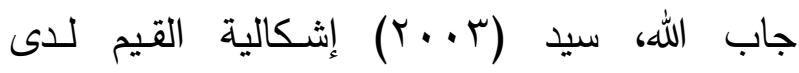
الثباب الجامعي بين ثقافة العولمة والثقافة التقليدية، مجلة كلية الآداب، جامعة طنطا. Merton Robert K. (1968).social theory and social structure,enlarged edition, the free press ,New Yourk.

Veroni, I. Eichelsheim, Buist, Kirsten L, Dekovic M, Wissink, IB.and FrijnsT.( 2009 ${ }^{9}$ ). Associations among the parent-adolescent relationship, aggression and delinquency in different ethnic groups: a replication across two Dutch samples, Developmental Psychology, VU University Amsterdam, The Netherlands

( Received: 22 October 2008 / Accepted: 10 May 2009 / Published online: 24 May 2009) https://link.springer.com/article/10.1007/s0012 7-009-0071-z 


\title{
The role of Family and School in crime prevention Field analytical in the UAE society
}

\author{
Prof. Said Nassif \\ Professor - University of Ajman \\ Sociology Department-College of Humanities and Sciences
}

And

\author{
Dr. Enaam Youssef \\ Assistant Professor - University of Ajman \\ Sociology Department-College of Humanities and Sciences \\ Sociology Lecturer - Ain-Shams University-Sociology Department-College of Arts
}

\begin{abstract}
. the main objective of the study is to identify the role that socialization institutions (family and school) play in protecting young people in the United Arab Emirates from crime, by conducting a field study on a sample of young people in the UAE community, as well as analyzing relevant scientific literature and sources related to the study. To achieve this goal, a questionnaire was designed to collect primary data from a consistent and convenient sample of 339 young people between the ages of 18-35 years (male and female). They were randomly selected from three emirates: Dubai, Sharjah, and Ajman. Besides, statistical packages for social sciences (SPSS) were used. To analyze the data collected through the questionnaire, statistical analytical methods were used such as the measure of the importance order, importance ratio and weighted average importance (multiple regression - variance) with a focus on the gender variable in each scale. The study reached a number of results, including:

-The importance of the role of the social worker and the psychologist, and the incorporation of the action plan of both in the school plan, and unified efforts to achieve the goals of protecting students from the social and psychological problems that lead to committing crimes.

-Organizing and implementing psychological counseling sessions by using individual and group methods that contribute to the protection from crime and criminal behavior.

-The importance of the role of socialization by providing ways to solve problems faced by young people is the highest percentage of any other measurements that fall under this field which comes along with gender disparity.

-The importance of transmitting cultural and social heritage from one generation to the next and the commitment to integrate with other socialization institutions are at the lowest level of importance. In addition, the obstacles that prevent the effectiveness of the role of the family and the school in preventing crime are the weak education that hinders the activation of the role of upbringing.
\end{abstract}

Key words : Family, Crime, School, crime prevention, socialization, socialization institutions . 